\title{
Од сећања до легенде: Теренска грађа као основ за реконструкцију портрета личности једне бајалице и социјалног контекста
} бајалаштва

\author{
Ана Савић
}

У раду се разматрају причања из живота забележена у селу Рибаре код Крушевца у периоду од 2012. до 2018. године од саговорника Цвете Милић (р. 1952), Мирољуба Савића (р. 1952) и Миодрага Ристића (р. 1942). Саговорници су изнели сећања на познату сеоску бајалицу и видарицу Негосаву Негу Ристић из села Рибаре. Говорили су о Негином животу, личности, мотивима лечења, магијском знању и бајалачкој пракси. Испитује се природа ових причања и начин на који она међусобним дотицајем формирају легенду о животу и личности бајалице. Указује се и на однос сеоске заједнице према бајалици и разматра социјални контекст бајања и народног лечења у патријархално-руралној заједници.

Кључне речи: бајалица, бајање, народна медицина, народно лечење, причање из живота, теренско истраживање, Рибаре (Крушевац), Србија

Теренски снимци коришћени за потребе рада ${ }^{1}$ настајали су у периоду од 2012. до 2018. године у селу Рибаре код Крушевца. Прикупљена грађа обухвата причања из живота и (ауто)биографска сећања трију саговорника из овог села: Цвете Милић (рођ. 1952), Мирољуба Савића (рођ. 1952) и Миодрага Ристића (рођ. 1942). Они су говорили о сеоској заједници и патријархално-руралној средини 50-их и 60-их година 20. века, нудећи приче проистекле из свакодневице и реалних ситуација везаних за конкретне личности. ${ }^{2}$ Међу њима се издвојио портрет локалне траварице и бајалице Негосаве Ристић, баба Неге.

\footnotetext{
${ }^{1}$ Овај рад представља измењену верзију мастер рада (Од сећања до повести: теренска грађа као основ за реконструкцију портрета личности једне бајалище и социјалног контекста бајалаштва), одбрањеног 28. 9. 2018. на Филолошком факултету Универзитета у Београду, под менторством проф. др Соње Петровић.

${ }^{2}$ Реални свет основна је грађа фабуле код усмених наратива који се темеље на људском искуству: „In other words, in experience-based narratives, the fabula consists
} 
Цвета Милић говорила је о Негиним вештинама, знању и пракси, као и о разликама између ставова мушких и женских чланова колектива о бајалаштву и народној медицини. Мирољуб Савић је у низу анегдота осветлио социјални контекст у оквиру којег се бајалица и њено знање позиционирају, док је Негин унук, Миодраг Ристић, изнео разна породична сећања па је његово казивање било обојено интимнијим тоном, покаткад носталгичним и емотивним. ${ }^{3}$

Приповедање саговорника пратили су појачана гестикулација и коришћење мимике и особене интонације, чиме је постигнута експресивност у говору (Bošković Stuli 1975: 153-154). Подражавајући говор, гестикулацију тела и експресију лица јунака својих прича, саговорници су непосредно представили њихово држање и понашање у одређеним ситуацијама.

Причања саговорника се приближавају у тематском и жанровском смислу. Иако они различито поимају исте ситуације, њихова сећања се преплићу и дотичу у једном чворишту, па сећање на исте догађаје и личности постаје тачка ослонца која омогућава извесно умрежавање сећања. Различита лична сећања послужила су као нити којима је изаткана прича о једној личности и представљена слика друштвеног живота, односа према здрављу, као и међуљудских односа, далеко сложенија и динамичнија него што је то случај са појединачно узетим причама саговорника.

\section{Реконструкција портрета једне личности - од сећања до легенде}

У опсежном раду о народним бајањима код Јужних Словена, Љубинко Раденковић истиче да је бајање „превасходно женска делатност" (1996: 16). Бајалица је, дакле, најчешће женска особа, а Раденковић је дефинише као „носиоца комуникативног чина у бајању и његов најважнији субјекат" (1996: 13). Фигура бајалице одређена је као централна фигура бајања и без њеног деловања, било вербалног - које се састоји у изговарању басми, било невербалног - које

of the real-world building blocks used for the construction of the story" (Blum-Kulka 1993: 364).

${ }^{3}$ Епизодичко памћење као важан сегмент аутобиографског памћења јесте „,konkretno, lično, često emocionalno obojeno (подвукла A. C.) i sačinjeno od predstava koje su vizuelne, auditivne, taktilne, olfaktorne itd. To je sećanje o nekim pojedinačnim situacijama, određenim predmetima, licima koje smo poznavali, radnjama i događajima u kojima smo učestvovali, a koji su uvek smešteni u određeno vreme i na određenom mestu i koji su važni u našem životu“ (Kovačević, Trebješanin, Antonijević 2013: 14). 
подразумева извођење магијских поступака, не постиже се крајњи циљ бајања, промена стања у коме се налази особа којој се баје (уп.: Раденковић 1996: 7-9). Верује се да успешност бајања зависи од вичности и умења бајалице, те од тога да ли су магијске радње спроведене по правилима.

По правилу магијска моћ расте са годинама, на основу чега се и бајалице хијерархијски позиционирају унутар свог еснафа, па су оне „најмоћније уједно и најстарије“ (Дивац 2003: 112). Од моћи и старости бајалице, што условљава и успешност бајања, зависиће њен углед у колективу (Раденковић 1996: 13). Искуство и успешност у лечењу умногоме су градили добар глас оваквих личности. Углед се стицао и неговао помагањем суседима и преузимањем важних друштвених улога (Brenko 2004: 324). Друштвена позиција бајалице је амбивалентна, а њена репутација у вези је са њеним социјалним и ритуалним улогама. ${ }^{4}$

Искази саговорника о рибарској бајалици Негосави Ристић показали су да је уживала поштовање заједнице, не само због дубоке старости већ и због помоћи коју је свакодневно пружала људима из ближе и даље околине. Негосава Ристић рођена је у другој половини 19. века, у селу Зубовац, али тачни подаци о датуму њеног рођења нису познати. Како није имала личних докумената, њене године се могу одредити оквирно, на основу података о рођењу деце. ${ }^{5}$ Извор Негиног бајалачког умења сеже у даљу прошлост, али није се могло тачно утврдити како је знање примила. Њен унук верује да га је наследила по женској линији из своје породице, а почетак бављења бајањем везује за удају. Мирољуб Савић сећа се да је Нега помињала да је знање наследила од мајке:

[3.4] Ја сам је слушао, па нам она прича. Она је тела да прича: - Микуло, дођи да ти кажем, неће ме шлуша ова Вукошава, шнаа, ништа не зна. И Милица ништа не зна. Ће помру, ће забораве, нема куј да памти, то шам научила од моу покојну мајку.

Поменути елементи везани за стицање магијског знања (наслеђивање по женској линији и активирање у моменту удаје 'завенчавање 6 са басмом) одговарају принципима који су установљени у истраживањима магије у традицијској култури. Бајалицом се

\footnotetext{
${ }^{4}$ О репутацији бајалица и њиховој амбивалентној позицији у колективу в.: Илић 2007: 148-149; Petrović 2018: 139-143.

${ }^{5}$ В. прилог $1.4,1.5,2.1$.

${ }^{6}$ Везивање бајања за свадбу заснива се на симболици коју овај обред има у традицијској култури, у првом реду због симболике прелаза, која носи обележје умирање-рађање. Зато време свадбе има посебну сакралну вредност. Тај однос се
} 
најчешће постаје у извесној старосној доби, онда када жена изађе из плодне фазе живота. ${ }^{7}$ Жена знање усваја пре прве менструације, а почиње њиме да се користи након менопаузе, кад престаје да буде полно активна и губи могућност рађања. Љубинко Раденковић везивање бајалачке праксе за 'чисте' жене види као култно-магијску условљеност, јер позиција посредника између света људи и света хтонског изискује раздвајање двају опречних принципа. Са једне стране, то је принцип мушког (семена течност, бело, творачко), а са друге женског (менструална крв, црвено, нечисто), који не смеју бити у додиру (1996: 16). Овај услов потиче од веровања да је жена у току менструалног циклуса нечиста, а као таква блиска је хтонском и потенцијално је опасна по заједницу (Radulović 2009: 173-178). Питање које се намеће јесте да ли бајалица високо место у заједници завређује због старости и моћи која са њом долази или се губљењем способности рађања, а са тим и улоге коју је до тада као жена заузимала, пред њом отвара могућност успињања на друштвеној лествици. ${ }^{8}$

Говорећи о народним лекарима на Балкану, Барбара Кериски Халперн запажа да се социјални миље на подручју руралне Србије споро мењао, те да су најважније социјалне улоге остајале везане за мушкарце:

Social structure, too, has changed relatively little. Rural Serbia still can be characterized as a land which is patriarchal, patrilineal and largely patrilocal. These factors have direct relevance to a discussion of folk healing. In this area it has always been men who have controlled the ongoing cycles of secular and ritual life, whether these deal with agricultural activites or religious and other annual rites. Women are excluded from such events except in prescribed female roles (Kerewsky-Halpern 1985: 320).

Један од начина да се завреди поштовање јесте помагање осталим члановима заједнице, а улога бајалице и народног лекара превасходно изискује такво деловање. Бављење бајањем и народном меди-

преноси и на даваоца и на примаоца бајања, а сакрално време учвршћује учињену промену (Раденковић 1996: 17).

${ }^{7} 0$ стицању бајалачког знања и започињању магијске праксе в.: Илић 2005: 228-229; Ђорђевић Белић 2008: 393-395; Petrović 2018: 143-146.

8 Лидија Радуловић истиче социјално значење термина којима се означава губљење плодности уласком у менопаузу, те у њима проналази обележја губљења досадашњег статуса и положаја у партијархалној заједници: „Termini kojima se označava menopauza kao što su: vreme, 'izgubila je svoje vreme', 'prošla joj perioda' takođe imaju socijalno značenje. Kada obično kažemo za nekog 'prošlo je njegovo vreme' želimo da kažemo da više nema važnosti ili ulogu koju je nekad imao. Dakle, ima socijalnu konotaciju gubitka položaja i statusa" (2009: 180). 
цином могло је обезбедити жени „izvestan autoritet i uticaj“ (Radulović 2009: 237), оно што јој родне улоге унутар колектива нису могле дати у таквом виду. Лидија Радуловић запажа да у литератури постоје тумачења која чињеницу да се магијске радње у већем броју случајева везују за жене, као и да жене испољавају виши степен религиозности у односу на мушке чланове колектива, објашњавају компензацијом за положај жена у друштву и њихово супримовање (2009: 240-241). Бављење овим позивом омогућава да се жена уздигне у традиционалном и патријархално устројеном друштву, а житељи могу да је прихвате као важан део заједнице једино ако је изгубила обележја родних улога. У исто време, уздизање бајалице као магијског функционера на хијерархијској лествици колектива прати и њена стигматизација. Бајалачка пракса поставља жену у лиминалну позицију и доноси јој трајну обележеност, па чланови колектива имају амбивалентан однос према њима (Radulović 2009: 244-245).

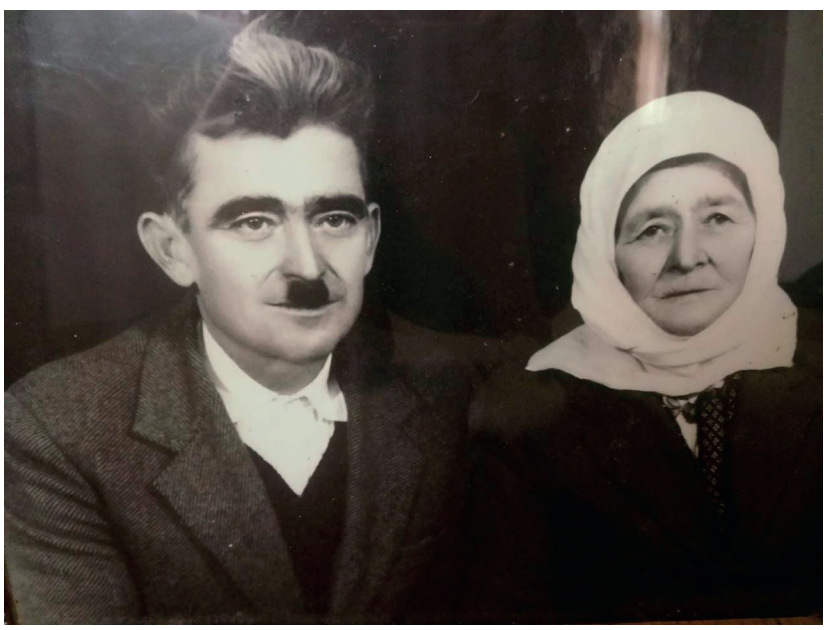

Сл. 1. Негосава Ристић са супругом

Нега је остала упамћена као изразито побожна жена, што је утицало на то да је заједница поштује и доживљава као узор. Ристић казује да је Нега редовно посећивала цркве и постила, а они који би се огрешили о верска правила заслужили би њену клетву:

[4.1] Па, беше клела овога попа Жику и ово. Затекла их на Велики... возио сам је у бању, па после иде на причес, Велики петак, у цркву. ... И однела увек она, за код попа, то је поштовање, и однела, овај, да даิ Мици, звала се та попадија Мица. ... И затекне де пржи месо. Јао боже. ... Није мало клела Нега. - Дабогда јој последње, па она, она... 
Религиозност, о којој су посведочили Савић и Ристић, потврђују редовно посећивање сакралних места, пост, причешћивање и поштовање које показује према свештеничкој породици на један од највећих хришћанских празника, доносећи дар. Са друге стране, овај исказ осветљава и хипокризију свештенства. Кршење правила и непридржавање поста на Велики петак јесте огрешење и о црквени канон и о обичајни кодекс, па отуда и оправданост клетве. Нега, као носилац народног и традицијског, постаје и чувар традиције и вере.

\section{Ослањање заједнице на Негино знање}

Негина делатност није везана само за бајања од урока, страве и других болести. Она је своју позицију учврстила и захваљујући познавању метода који су се темељили на рационалном деловању и емпиријским вештинама, као што су коришћење лековитог биља', намештање костију, акушерство. Њена се помоћ тражила и очекивала не само у кругу рођака, блиских пријатеља и комшија, већ и шире. Објашњавајући Негину улогу у акушерским захватима, Мирољуб Савић истиче да су јој се за помоћ обраћали и из оближњих села:

[3.3] Али, пошто није било гинеколога, баба порађала сваку жену, али сваку. Ђунис, Каоник, Шиљеговац, Зебица, Гревци, Рибаре, Зубовац, Росица, Бољевац, Рлица и Срндаље. Али сваку од моје генерације. Значи, свако дете до пре два-тридесет година које се родило, она га је породила. Значи, то се знало, она је била гинеколог. Сваку краву истелила, свако теле, сваку овцу, сваку свињу и сваког је излечила.

Недостатак лекара или њихова недоступност пре, али и у првим деценијама после Другог светског рата, и тешка материјална ситуација становништва, засигурно су допринели томе што су народни лекари, видарице и бајалице постајали незаобилазни у свакодневном животу (Brenko 2004: 329). Од њих се помоћ очекивала у сваком тренутку, а становништво, чак и онда када је могло потражити помоћ стручних лица, често није желело да одступа од традиционалних начина лечења. ${ }^{10}$

\footnotetext{
${ }^{9}$ Аида Бренко коришћење лековитог биља ипак поставља на границу између рационалног и ирационалног лечења и истиче да су народни лекари поседовали емпиријско знање о биљу, али и да су веровали у његове магијске моћи (Brenko 2004: 323).

${ }^{10}$ Истицање бајаличине супериорности у односу на лекаре и званичну медицину опште је место у причама о успешним излечењима (Ђорђевић Белић 2011: 176; Илић 2007: 154; Petrović 2018: 151-152).
} 
Присећајући се детињства и прележаних дечјих болести, Мирољуб Савић говорио је о Негинима бајањима и познавању лековитог биља. Она је поседовала сандук пун трава којима је успешно лечила озбиљна обољења:

[5.1] Она има пун ковчег, то је једна шкриња велика са тим сувим травама. Лечила она ефикасно жутицу, лечила. Жутицу, за жутицу се иде у болницу, а баба је то лечила травама као руком овако.

Савић је описао лечење од уједа пса и тешке инфекције које је без лекарске помоћи Нега санирала.

[5.2] Неке траве, по градинче, тамо начупа, оде кући, донесе нешто из ковчега, неку суву траву и сумпор. ... И стави ти маст и стави то да се кува у чорбалук један, на шпорет. ... - „Ша ћу ти ја направим мелем, за три дана ће ти прође, немо се шекираш, није то ништа." Направи она неку муку, а мени само нешто сева, само сева. ... То загнојило, овако дебело. Она то мени препра с неку млаку воду, неке крпе, тамо пра, кува нешто, некакву дезинфекцију, баба не знам шта му ради око онај шпорет. Напуни оне ране са оним мелемом од сумпора. Знам да је сумпор био главна ствар и много неких трава. Напуни то, завеза. За три дана је то спласнуло, ја мало, по мало проходах - ево, и дан-данас имам ожиљке ту, а од тад има четрдесет, как, педесет година. Пуних педесет година има како се то догодило и никад ми ништа није било.

Описани догађај одиграо се 60-их година 20. века, када је становништво села већ могло потражити помоћ лекара који је био постављен у оближњој вароши, десетак километара од Рибара. Ипак, и ова раздаљина представљала је тешкоћу, посебно у ситуацијама које су захтевале брзо реаговање. Моторна возила тада су још била реткост, а аутобус је овом релацијом пролазио само једном дневно. Ослонац на народне лекаре и бајалице стога је био најбржа и најчешће коришћена опција.

Ипак, и нешто касније, када је до лекара било лакше доћи, било је оних који нису желели да одступе од устаљених навика. 0 томе сведочи сећање Цвете Милић.

[6.2] Кад било за мене да родим Лелу, ја нећу да идем у Крушевац. Ишла сам четири-пет пут, Ано. Било ми тешко. И терали ме четири-пет пут, по болнице сам лежала. И кад беше да се породим, кад да се породим, мене се не иде у болницу. Ћу терам да доведу баба Негу горе куд стару кућу да ме баба Нега порађа. И 
баба Нега дође, узе ме баба Нега. С Милицу и с моју свекрву на једну чергу, на једно ћебе, па ће љуљав, љуљав, лако ћу се породим.

Видимо да су на однос према лекарима утицали разни чиниоци. C једне стране, Цвета избегава да се обрати лекарима због тога што многи претходни одласци у болницу нису побољшали њено здравствено стање. Са друге стране, однос према Неги је приснији, она оличава велико искуство. Занимљиво је да саговорница, кад описује моменат Негиног доласка и преузимања контроле над ситуацијом, себе поставља готово у положај објекта („И баба Нега дође, узе ме баба Нега"), доживљавајући је као ауторитет.

Из причања Цвете Милић о искуству рађања детета ван болнице можемо реконструисати Негин приступ или барем неке његове сегменте. Стављање породиље у ћебе и љуљање показује да се Негина акушерска вештина заснивала не само на емпиријском искуству и знању већ и на магијским поступцима. Према веровању, љуљањем се тело ослобађа од злих духова, што се најчешће практикује током Беле недеље (СМР 209). Љуљање се изводило приликом порођаја како би његовим катарзичним дејством породиља била заштићена од демонских утицаја и како би се лакше породила.

Цветин став према традиционалним методама лечења променио се након дугог низа година. Поверење које је као тек удата девојка имала према традиционалном начину порађања нестало је, па из перспективе зреле жене процењује да је тадашњи избор био погрешан:

[6.3] Де... не могу, ја сам примала инекције, одржавала сам трудноћу. Де се мог породим без лекари!

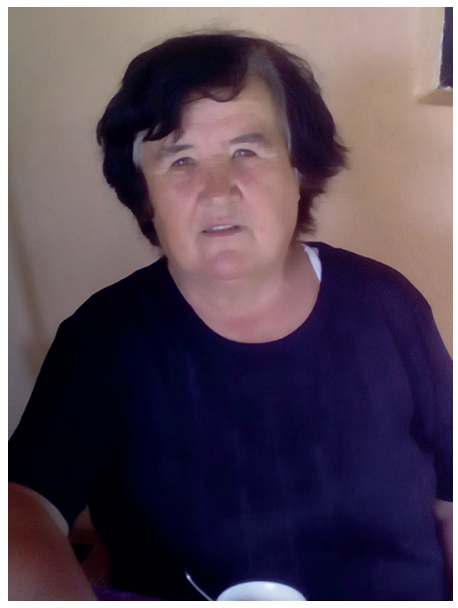

Сл. 2. Цвета Милић 
Цветина прича није открила само варијације у њеном односу према традиционалној медицини и бајању, условљене временском дистанцираношћу од готово пола века, већ и осуду мушких чланова заједнице. Док жене помажу породиљи и Неги, Цветин свекар, домаћин куће, свестан је ризика по здравље породиље и детета, што имплицитно подразумева да се поштује регуларна медицинска процедура.

[6.4] И баба Нега сву ноћ ме порађа и деда то чуо, деда Станко, па кад наиђе, па, кад викну на њи: - Еј, ако на ту жену шта фали, ако умре жена ил то дете се не роди живо, ја ћу све вас у робију да ве отерам! И баба Нега престаде. Неће баба Нега да ме порађа.

Цветин амбивалентан став према Негином знању вероватно потиче од чињенице да порођај на традиционални начин није успео, те да је на крају ипак била одведена у болницу где су јој помоћ указали лекари. Слабљење поверења у бајаличине вештине вероватно је условљено и неуспешним предвиђањем пола детета:

[6.5] Ал вика баба Нега: - Мушко ће да роди, мушко, Свети Лукан, крупан! Кад ја отидо у Крушевац, ја после, породише ме, ја тражи мушко дете.... А оно женско, а баба Нега вика Свети Лукан! Каки Лукан!

Ипак, поверење саговорнице према народној медицини и бајалаштву није у потпуности нарушено. Она је, наиме, покушала да усвоји нешто од Негиног знања, а и данас се сећа једне од њених басми. Басму против урока и сама је употребила, уверена у њену делотворност.

[6.6] Па, ето знам ту басму. Млого лепа басма. То видиш. Јелена зна, бајала сам јој. И било јој добро.

Цвета није у потпуности усвојила знање због страха да ће се женски чланови Негине породице томе противити, али њена прича показује да је поверење према овом знању опстало:

[6.7] Бајала све, све знала. Да има стока млеко, да, све. И мене терала. ... Да научим. - Јеси писмена? Реко: - Писмена. - Е, ајде ти пиши, а ја ћу ти причам. Ће ми она прича, а ја да пишем. И полази с мене до онај бандер онде, ће дође куд нашу кућу да ми прича. А Вукосава и Милица, знаш, ће се наљуту оне. - Баба Него, врати се. Ће се наљуту Вукосава и... - Ће ми даш мало ракију да пијем и да напишеш све што ти ја причам, ти напиши. И тако, после ће да знаш. И ја не тедо ће се наљуту ови. 
Миодраг Ристић жене означава као свакодневну Негину клијентелу, а две анегдоте најбоље осликавају однос мушких и женских чланова колектива према њеној пракси. Прва анегдота на комичан начин приказује прислушкивање чина бајања као вид мушке забаве:

[7] А покојни Драгомирче, овај из Гревце, Бинин ... Каже, жене рој долазе код [Неге]... нон-стоп. А овога није мрзело да се, овај враг, скине ово, од обор, знаш, покривао са ћеремиду цреп, онај стари обори. И њега није мрзело, него скине се, а он спадало био. То је био спадало човек. И дотрчи поред кућу и код басамак чучне, склони се. А ова у ходник, отворена, топло време. И то бацала жарчићи и то бајање. ... А он слушао, није, да се не појави. ... А после ми исприча: - Eј, све сам чуо! Јао, мајко мила! Па, то ти шокови.

Драгомирче нарушава интимни тренутак у коме се успостављају поверење и интима између две жене, једне која долази због личног проблема (породичног или здравственог) и друге која је ту да понуди разговор, савет или обави конкретну радњу како би отклонила проблем. Он је припадник млађе генерације, има репутацију шаљивџије, традицијска правила поштовања табуа га не оптерећују, а основни циљ подухвата јесте збијање шале и ругање веровању у моћ бајања, који вероватно сматра превазиђеним.

Друга анегдота, такође обојена хумором, приказује из мушке перспективе колико су сеоске жене заправо биле везане за баба Негу и доживљавале њену делатност као неопходну и незаменљиву свакодневну помоћ. У тренутку када се селом проноси глас да је Нега преминула, женски део колектива запада у дубоку жалост.

[8.1] Сладолеџија. Сладолед. И он јој да бре ... Он толико то имао поштовање. Уууу бре! Колко пут и долазио овде ... И он јој да. Наишла она, дошла... - Еј, баба Него, ајде овамо. Дао јој онај сладолед, она вероватно ... била врућа. И онај, а ладан сладолед. И пошла за, за горе, за код ћерку, у Лазићи и - дринг! ... Падне, значи, вероватно је жигнуло оно од хладноћу. ... А стара. И то, и уз тарабе... и жене, ту, народ се прикупио. Жене, каже, кукање и бијење у главу за Негу. Свеће испопаљене. Одма ту продавнице, знаш. Упалили свеће.

У наставку анегдоте Ристић изводи шалу са женама које увелико припремају дочек и наглас наричу. Обрт који настаје када угледају Негу да из аутомобила излази жива и здрава извор је хумора, а духовитост лежи и у начину на који саговорник описује и подражава њихово тужење. 
[8.2] И ја бабу натоварим и сад да видиш шок. Станем ја за Дарину, за ћерку. ... И сад види ово. Док сам ја то, док та драма се одигрувала, све растребена соба. Покојна Драгица, покојна Драгица, Цана, да л’ беше Милосија, још не знам кој. Скупило се ту, све то растребено, жене. ... И сад кад ја долазим, они на капију. Дочекују. ... И кукууу, кукау они. А ја нећу да станем, него... Ја долазим, ово. Оне седеу на капију. ... Дочек, дочекују Негу - умрела Нега. Ииијао! Не знам сад. Ијао ово. Ја кад се сетим, Драгица: Ијао, бабо, и куку, бабо! А ове? Јао, Боже кој је то циркус. Излази Дарина, ја преклапам оно седиште. Једна само врата. Тако је на фићу. ... Извукујем... Кад видоше Негу, оне испопадаше. Жива Нега. Џабе ти оно! Јао Боже! Јао мајко! Кој је то хумор био! А кој дочек, кукање! То све. А у Рибаре исто. И реко... а после реко, еј, колико гу жене жалиле. Па, свакем пружила помоћ. Која би то, реко, то би земља ... И после живела она.

Под утицајем и притиском мушког ауторитета оличеног у старешини породице, долази до промене односа према магијској пракси која припада женској сфери деловања. Женска сфера остаје везана за традиционално и неофицијелно (ослањање на традиционални начин лечења и порађања), а мушка за савремено и официјелно (поверење у лекаре, савремену медицину и прописе власти). Како показују социолошка истраживања, еманципација жена у руралним деловима Србије у првој половини 20. века и даље је била у заостатку у односу на еманципацију мушкараца, који су имали више могућности да на краћи или дужи временски период (услед одласка у војску, током школовања или ради радних и трговачких обавеза) напусте патријархално-руралну средину и упознају начине живота у културно и социјално развијенијим местима (Isić 2008: 49-79). Међу женама су одлазак на рад или школовање још били ретка појава. Њихов поглед на свет спорије се мењао, па су остајале везане за већ усвојене навике и, будући присније с бајалицама, и даље су у већој мери него мушкарци од њих тражиле помоћ. Патријархалност и стид су их чвршће него што је то случај са мушкарцима усмеравали ка заједници и устаљеним моделима понашања. Због раније наведених разлога, као и због осећаја стида, жене су у мањем броју одлазиле лекару јер је то подразумевало обраћање за помоћ некоме кога не познају и ко је најчешће био мушкарац.

Из казивања саговорника следи да је Нега била цењена и да је уживала велико поштовање читаве заједнице, у извесном смислу чак је имала више-мање формални статус почасне личности (бесплатно је посећивала оближњи турски амам, бесплатно се возила аутобусом, доношени су јој бројни дарови). Ипак, перцепција бајања се разликова- 
ла. Мушкарци су табуисаност магијских радњи могли да наруше било из протеста, било из жеље да се створи хумористична ситуација и заподене шала, док су жене имале приснији однос са бајалицом.

\section{Аспекти Негиног знања}

У оквиру своје заједнице Нега је имала различите улоге, а једна од њих била је везана за прекидање трудноће. Недоступност лекара и могућа забрана абортуса, уз потребу да се захват изведе у тајности због потенцијалне осуде мештана, несумњиво су велики број жена навели да помоћ траже од бајалица, што довољно говори о социјалним приликама у оквиру патријархално-руралне средине. Обраћање за помоћ ове врсте је захтевало велико поверење у вештине, знање и саму личност баба Неге. Из исказа саговорника могу се реконструисати само неки елементи овог поступка:

[3.1] Ал да ти причам, баба Нега се бавила абортусима. И долазе жене да их абортира.... Кад дође нека жена, она је савије на дрвено корито. И она то с неком, чиме она то ради, неко вретено, неке муке, то је страшно болно. Али то ове што се курвају, сељанке, оне дођу ил' неће да чувају више децу, шта знам. И она то радила врло успешно.

Због оваквих захвата Нега је имала спор са властима: ${ }^{11}$

[3.2] Али јој се десило једанпут да је нека жена добила тровање и заглавила у болницу. Дошла полиција, Дрндаревић неки: - Ајде, бабо. Водили они њу, испитивали је. Исприча она како је било и пустили је, ништа није било тој жени. И запретили њој да то више не ради.

Оно што је Неги засигурно донело највеће поштовање и што је допринело да се брзо заборави поменути случај јесте успешно лечење стерилитета и код мушкараца и код жена. Цвета Милић казује да је Нега управо по томе била чувена и открила једну од Негиних магијских радњи за отклањање стерилитета:

[6.1] Па, причали за њу потпасувала жене да остану трудне. ... Стомак ги потпасувала с тканице. Потпаше ги баба Нега и оне остану трудне.

\footnotetext{
${ }^{11}$ Случајеви затварања и саслушавања бајалица нису били ретка појава јер званичне власти не одобравају бајалачку делатност (в. Petrović 2018: 153; Ђорђевић Белић 2011: 184-185).
} 
И друга два саговорника потврдила су да је Нега успешно лечила бездетност. Мирољуб Савић описује начине лечења:

[9.1] Она је знала да лечи стерилитет. Али га лечила на неки такав начин безвезан да то није нормално, шта она дала да поједу и да попију, ја не знам. ... Сад она њих прегледа тамо. Ону госпођу, ту сељанку подиже, подвеже је са неким тканицама, подиже јој стомак, шта јој ради тамо, не знам, враћа јој материцу, неке муке ради. Ономе госп... младожењи нешто даје да пије, неке травке.

Поред поступака за магијско поспешивање плодности жена, Негин приступ обухватао је и разне припреме које су подразумевале и друге видове знања. Тако Мирољуб Савић успешност праксе објашњава употребом биља, док магијске радње сматра несхватљивим и смешним. ${ }^{12}$

Иако у магијске аспекте лечења не верује, Савић прецизно објашњава поступак који треба да буде извршен на раскрсници. Спајање раздвојених кола и враћање клина треба магијским путем да обезбеди зачеће. Епилог приче осветљава однос тадашње заједнице према извршењу ритуалне радње која подразумева полни чин на јавном месту. Чланови колектива поштују табуисаност радње и не ремете њено извођење, чак се повлаче у куће. Иако Савић понашање мештана објашњава стидом, могуће је да они не желе да ремете обред који за циљ има настанак новог живота. Уверен да је овакво делање резултовало зачећем, саговорник као потврду веродостојности приче наводи дарове које је Нега добила након рођења детета.

Баба Негино знање задирало је и у област ветерине. Савић износи анегдоту о томе, и уз веома живописан дијалог сликовито дочарава ситуацију:

[10] И, баба, сећам се ја, затели се њима крава, отели се и изручи се, испадне крави материца, крава легла, а Брана ветеринар, доктор. ... Знаш, крава неће да устане. Брана псује, ладну воду, пере оно, покушава да врати оно у ону краву. А она дошла с једно тојаче, била стара, она тад имала деведесет година, сигурно. Па, лупа у калдрму, тап, тап, тап: - Добар дан, доктуре! Она га виче доктуре. Он ништа, она опет, чук, чук, чук - Добар дан, доктуре, поможи бог, доктуре. Он: - Бежи, бабо, у пичку материну! - Доктуре, то ше не ради тако. Мене боле руке, ја не могу. Шлушај да ти кажем... - Шта знаш ти, бабо! Која је ова баба? Па, то баба Нега. - Ти си та баба Нега! - Ја шам баба Нега, то моа

\footnotetext{
${ }^{12}$ В. прилоге 9.2 и 9.3.
} 
кућа, мој унук офичир, дабогда и ти да имаш тако! Чекај да ти кажем... - Шта ће ми кажеш, бабо? - Ужни врућу воду, па опери ту шламу и ужни маш, па намажи то, па доведи куче да лане на краву да ше дигне. Па, врати у краву, па ужни канице, па вежи под трбу, па жавежи - јако, да гу држи, да ше више не ижручи и не дај да легне крава, мора да стоји! Да дође куче да лаје краву, крава ће устане, нећ да устане, крава ће да умре. Он је гледа: Донесте врућу воду и тај мас! Он доктор, еј, доктор ветерине не зна шта да ради! Он ће је сече, ће је оперише, ће гура оно силом. Он то уради све то како баба рекла. Више никад није дошо. Кад дође баба негде да прича како се крава тели, он кад чује баба Негу, он се врати. Баба је била велики стручњак.

Баба Нега, жена великог практичног искуства и традиционалног знања, подучава и посрамљује младог ветеринара, образованог у некој од званичних институција. Савић њихов сусрет вербализује уз богату гестикулацију и подражавање њихових гласова, интонације и држања, не би ли што непосредније представио актере, и поентира похвалом Неги.

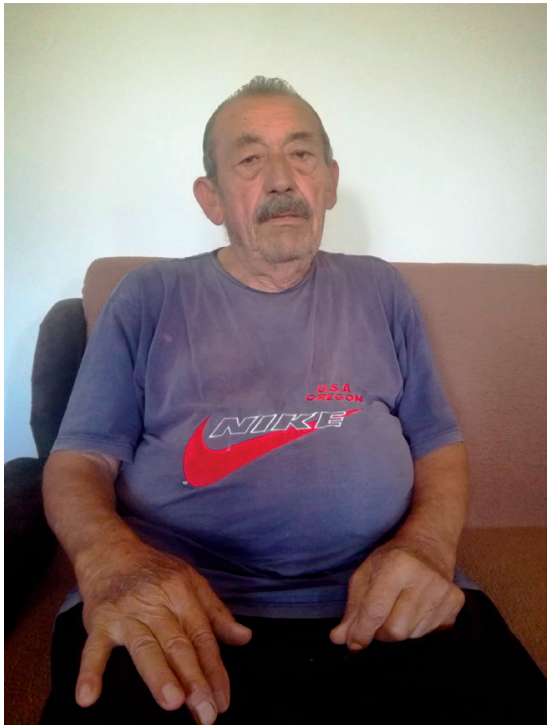

Сл. 3. Миодраг Ристић

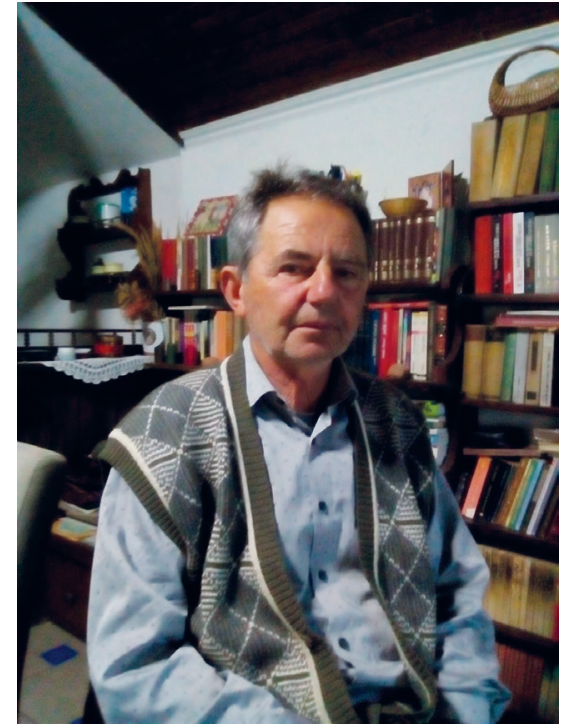

Сл. 4. Мирољуб Савић

Ристић је испричао исту анегдоту и такође на крају истакао да се ветеринар после овог догађаја увек повлачио кад год би чуо да је пре њега у помоћ притекла баба Нега („После кад је дошо Брана ветеринар, доктор, он је, само ли чује ... Каже: - Чим била Нега, значи не треба Брана ветеринар“). 
Нега је за заједницу у још једној области била незаменљива. Ристић се присетио да је успешно лечила уганућа и друге ортопедске повреде, а најбројнији пацијенти била су деца. Третман је обухватао масажу повређеног зглоба и његово враћање у првобитан положај („Падне и ичанчи руку, не може, и ово. ... И она у топлу воду, то накваси. ... Масира, и оно. Намести“).

\section{Употреба лековитог биља}

Негосава Ристић остала је упамћена као велики познавалац лековитог биља. Мирољуб Савић сетио се њених упутстава за лечење змијског уједа. Она је користила траву чији су листови имали шаре сличне шарама змије. Магијска повезаност биљке и животиње почива на сличности па се, према веровању, она користила за извлачење змијског отрова из ране.

[3.4] Она има пун ковчег, то је једна шкриња велика са тим сувим травама. Чак од уједа змије имала неку, неку, неку траву, неку белу боцу, па је лист од те беле боце... То никад више у животу нисам видео. Де пчеле, то могло ту да расте, у њен пчеларник, она имала трмке, није кошнице. ... - Виш ову траву? Виш да она, ишта ти је као жмија шарка на грбину шарена. Е, то кад те жмија ује, иштучаш одма и туриш на рану и шве отров ижвуче. Можеш и да ишпијеш, ко ти ждрави жуби. Ал' то ижвуче отров, то много добра трава.

Једна друга биљка више је заокупила саговорника. Он се присетио детињства, када је за пет „банки“ асистирао баба Неги приликом тражења врло специфичне биљке. Према његовом сведочењу, сакупљање ове биљке обављало се уочи Ђурђевдана или дан после овог празника, а захтевало је строго ћутање како биљка не би „побегла“ од трагача:

[11] Али, има једна трава која не расте изнад земље, него та трава као тартуф - печурка, има плод у земљи, на, на два риљача негде, на једно четрдесет сантиметара, четрес пет. Е, по њеном веровању, можда је то истина, ја не знам, ако се прича, трава не може да се ископа. Она бежи, каже, све дубље и дубље, има да копаш два метра. И она мени: - Мико, ћу ти дам пет банке да пођеш да ми ишкопаш траву ... И сад, ја узмем мотику за пет банке, баш ме брига, има да купим бомбоне ... Што да јој не копам? И ја пођем њој да копам ту траву, ал она мени каже: - Ту ше не прича. Ја ћу да ти пипнем шаш тојагу уш коју траву она раште. Она нема горе лишће. Та трава у жемљу. Мора копаш два риљача. 
Ако проговориш, она шве дубље иде. Ја ћу шам да ти пипнем ш тојагу де, а ти ће копаш.

Биљка се доживљава као биће које има карактеристике човека може да чује људски говор и пред човеком побегне у земљу. Љубинко Раденковић овакве биљке карактерише као чудотворне и истиче да се до њих тешко долази јер „при покушају човека да их ископа, оне саме ‘беже'“ (1996: 215). Према речима саговорника, ова биљка расте испод земље у виду кртоле и једини начин да се препозна место њеног станишта јесте да се пронађу друге биљке које расту у њеној близини.

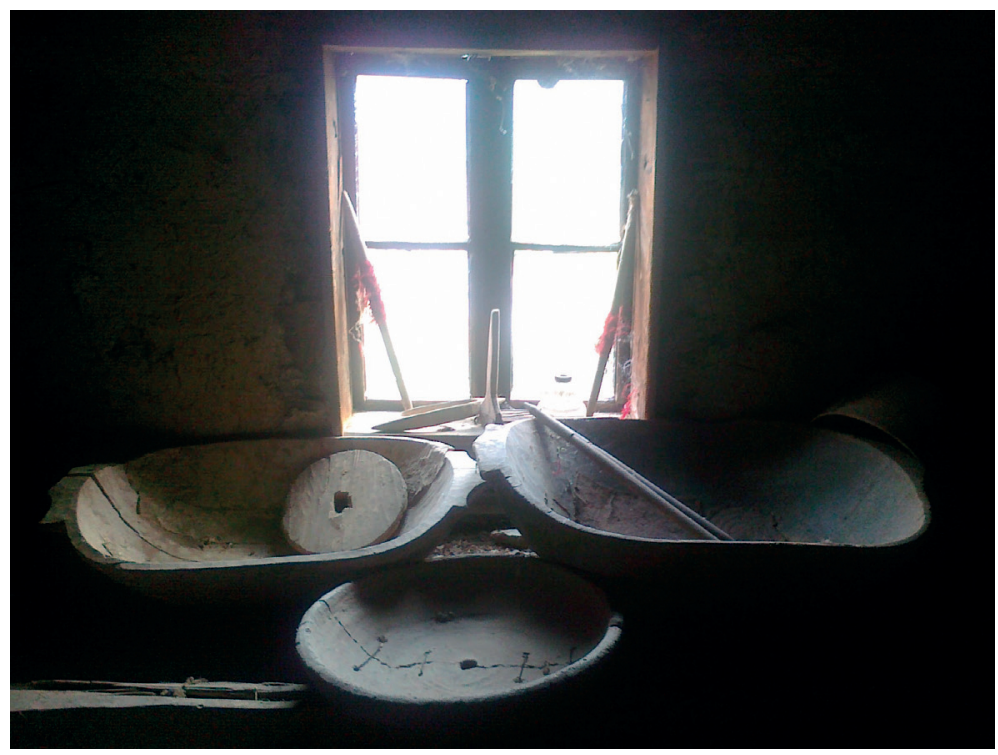

Сл. 5. Вагани и црепуља на тавану старе Негине куће

\section{Бајања}

Нега је остала упамћена и по бајањима. Уочи Ђурђевдана Негу је походио велики број жена како би им направила крмила за стоку. Ристић није упамтио басме које су биле саставни део магијских радњи за враћање одузетог млека, али је упамтио да је постојало веровање да извесне жене кравама могу одузети или смањити млечност, те да се уместо млека након бацања чини појављује крв:

[1.2] Па, кад буде за крмила уочи Ђурђевдан, брање трава, оно, и Зебица, и Крушинце, и Срндаље, и Рибаре, и ово, Зубовац жене, с оно, с она крмила за стоку.... Сас оне травке, донесу. Три- 
це и оно. Уочи Ђурђевдан. Па, за краве, за овце, шта знам. То правила.

Нега је умела да поништи дејство чини, а Ристић је упамтио само део магијских радњи које ваља извршити над стоком:

[1.3] И чујем де гу прича, узнеш јаје, и како треба се баје, па га из... од рогови, ово. Па, тамо позади, да га сломи, знаш, низ кичму, па да баци. Ал' прича гу како треба, шта да каже. Онда, овај, кој ти обрао, да л’ беше три главице бели лука и паприка, ово-оно се меша у оно трице, она то набаје. И то да ујутро рано, пре сунце, накрми краве.

Нега је умела да спасава и од живака, демона болести које врачарице шаљу човеку коме желе зло. Људи су пристајали на поступке оваквог лечења не знајући да тиме могу угрозити сопствено здравље. Нега је за одбијање живака, као и многе бајалице тога доба, користила живу, опасну по здравље:

[12] Плус ово, ја реко: - Него, немо, лебац ти... Једна кад се... да л’ из Љуптен, одакле дошла... па гу давала... има живака. Као намењено, живак је... то је. Па, то ти је те врачарице што пратиле. ... А она да је запоји, а то је отровно. Жива, јебем ти. ... И она ју после баје нешто. И запоји је с оно, кад изломе топломер са живу. Метла и шта беше још? Не могу се сетим то. Шта се држи докле то баје и запоји је што је учињено, знаш. ... Па, значи од тог живака. Да л' је на... нагазила на... ил' учињено. ... Па, дабоме, попије. Еj, боже.

Фрагменте једне од њених басми за лечење болести која се у народу називала русом и доживљавана је као антропоморфно биће, запамтио је Мирољуб Савић:

[13] Знам само уводно. Ја сам био дете, па ме није занимало. Па, то руса, то је нека лиша, знаш. И она то нешто поред плота, нешто тамо с балегом, не знам како. Али ја знам, сећам се, ми приђемо, деца, играмо се, па да чујемо: Трута Русу проси, Руса Труту неће, венуће, трпеће, за Труту неће.

Руса је представљена као антропоморфно биће женских карактеристика, док име Трута настаје као игра гласовног подударања. ${ }^{13}$ Руса се усмерава ка Трути, односно ка варијацији сопственог бића. Пристанком на удају она пристаје да буде „испраћена“ далеко од човека, а

\footnotetext{
${ }^{13}$ Удвајање и варирање имена демонског бића (болести) треба да обезбеди његово усмеравање самог на себе, па самим тим и напуштање човека (Раденковић 1996: 51).
} 
њено непристајање само је борба против одступања. Глаголи венути и трпети магијском моћи речи осигуравају њено слабљење.

И Ристић наводи да је баба Нега умела да „баје од русе“. Мада није упамтио текст басми, описао је магијски поступак који их прати:

[14] Изведе, па на плот, биле онда, па знаш, оне прошке. И она баје, баје, ово, па залепи ову говеђу балегу на прошку, па тако опет иде поред ово и баје да би скинула ово, све оне плое по руке.

Говеђа балега лепила се по даскама плота у виду ситних љуспица, што је требало да опонаша изглед болести. Магијским деловањем она се симболично одвајала од тела оболелог и преносила на неживе предмете, што је требало да обезбеди оздрављење.

Баба Нега је успешно бајала и против страве и урока, а оба саговорника дала су вредне податке о магијским поступцима који су били нераздвојни сегмент бајања. Миодраг Ристић објаснио је како се добија страва и како изгледа препознавање узрочника:

[15.1] Гледао сам, ето ти, запева петао - дете писне [у позадини се чује петао]. ... Знаш, плаче. И доноси, она му баје то, и узне брашно и баца - и тачно се нацрта ... На, на, од оно кад баци од оно брашно кад баје, да од петла или од куче. Тачно се нацрта.

Страва је међу јужнословенским народима препозната као стање проузроковано страхом или траумом, а може се манифестовати и као психичка и физичка онемоћалост. Она такође може имати карактеристике демонског:

The strava - fright is the name of the disorder, but also is the cause of it - it is imagined that it acts as a creature coming from the upper world which enters into the body of an individual and if not treated consumes it (Vivod 2014: 10).

Верује се да се и деца и одрасли могу престравити, а узрочници могу бити различити - од свакодневних (као што је певање петла) до демонских ${ }^{14}$. Важно је да бајалица препозна узрочника, а његово откривање подразумева магијску радњу: она баца брашно на огаравела врата, а слика која се појављује одаје узрочника страве. Мирољуб Савић детаљно описује овај поступак:

[16] И, гледала у брашно. Била једна врата, огњиште позади у стару кућу. Е, та врата су била гарава од дима. Онда, ко је бо-

\footnotetext{
14 У традицијском поимању света узрочници болести представљени су антропоморфно. То су заправо демонска бића, оностране креатуре опасне по човека (Раденковић 1996: 35-43).
} 
лестан или има неки проблем, он оде и она гледа у брашно. Она избаје, избаје, избаје и узме шаку брашно и баци на врата. Као ја кад гледам у кафу. На вратима се, врата су црна од дима, брашно је бело и онда се направи једна фигура. И она тумачи ту фигуру.

Брашно је у народним бајањима често коришћена материја и употребљава се у магијским обредима за лечење од страве (Раденковић 1996а: 126). Саговорник је, међутим, тек приликом другог интервјуа гатање помоћу брашна везао за бајање од страве, док је у првом интервјуу истакао да је баба Нега на овај начин сазнавала о узрочнику болести или неког другог проблема.

Говорећи о топљењу олова како би се открила особа која је оболелом начинила зло, Мирољуб Савић је ову радњу одредио и као начин да се препозна узрочник страве: ${ }^{15}$

[17] Она стави онај куршум, знаш, у неку кашику или можда у неку конзерву и са машице на, над ватром и олово исцури, оно се топи лако. Е, онда олово проспе у воду кад баје. ... Од тог олова, кад оно врело олово се сипе у хладну воду, направи некаква фигурица, оно знаш? Ражљеби се нешто, личи на неку караконџулу, неку муку, нешто... личи на мајмуна. Е, онда као у шољу гледа: - Е, еве, види! Учинили ти, тачно. Ааа, да ти бајем од стра. Учинили ти. Е, еве како ше направило од олово! Поглеј. Направи се нека фигурица и она тумачи облик те фигурице.

Нега је гатала и уз помоћ жара и белега. Ристић наводи да је умела да скида чини са особе за коју се верује да јој је нешто учињено и при томе користила угљевље и белеге:

[15.2] И ено ти, они жарчићи што је бацала, за то чиње, за ово, и од кога белег од кошуљу и ово. И не знам како жар из шпорет. И она вода, сипе. И она то баје и баца. И ово, тачно за кога мисли да је ово... Ако се не увати за онај белег. ... Кад набаје, ако је, за кога сумњаш, значи тачно се увати онај жар ... За жар дабоме - чврррр. Кад га баци у воду, и дође и увати се.

Белег је узиман од особе за коју се сматрало да пати од бачених чини и представљао је део или кончиће тканине, а погађање ко је чини бацио зависило је од тога хоће ли се белег на помен одређеног имена ухватити за угљен. И Мирољуб Савић причао је о овој радњи, али је истакао да је Нега на основу (не)хватања белега гатала у коју цркву особа треба да оде и ком свецу ваља да се моли како би оздравила:

\footnotetext{
${ }^{15}$ Олово је бирано за магијске радње због својих карактеристика, лаког топљења и мењања облика, као и сиве боје, која у себи обједињује принцип црног и принцип белог (Раденковић 1996а: 137).
} 
[18] Узме из огњишта, баци га на земљу и машицама чука, разбије онај жар и узме га у руку овако. Знаш, пребаца га из руке у руку, нешто баје: - Ајде да видим шад од чега ти је. Па, га баци: - Eеe, нее, није се уватило за белег! И баци она десетак тих угљена, знаш. И обично баца за, намени цркву де да идеш. - Да ти бацим да видим... аааа, болешно ти дете. Еве... Зна, знаш. - Е, са ћу ти кажем у коју цркву. Није ти за Света Петку, немо д' ијеш тамо ... Е, да ти набајем за Света Богородицу. Није ни тамо. За свето... увати се за Светога Илију. Да водиш дете у Свети Илију. Еее еве увати се за белег! И онај га води. И она ту воду после, тај кога она лечила пивне, попије, знаш. Умије се и иде у цркву де она каже и после му буде боље. То, обично је бивало.

Баба Нега је оболеле и унесрећене слала у оближње цркве и манастире како би молитвама искупили своје грехе и дошли до оздрављења. Ваља запазити да Нега не представља себе као неког ко може да отклони болест самостално, већ само као посредницу, медијум који ће оболелом открити да је болест дошла као казна за непоштовање одређеног свеца или пак упутити унесрећеног ком свецу треба да се поклони.

Према исказима саговорника, Нега је лечила и од урока, а наведене радње су биле практиковане како би се открио узрочник урицања. ${ }^{16}$ Народ је веровао да су основни узрок урицања зле очи, те да управо од урока „највише света умире“ (Ђорђевић 1938: 7). Ристић преноси веровање да поједине особе имају моћ да урекну и нанесу зло погледом („То каже има гадни очи, па те урочи“).

Мирољуб Савић сетио се фрагмента једне од басама: „Пошла девојка, пукла гу сиса“. Фрагмент садржи мотив пуцања ${ }^{17}$, на основу којег басму можемо повезати с групом басама за отклањање урока ${ }^{18}$ јер је управо он један од најчешћих њихових мотива (Раденковић 1996: 60).

\footnotetext{
${ }^{16}$ О магијским радњама за скидање урока в. Ђорђевић 1938: 301-324.

${ }^{17}$ Пуцање еротизованог дела тела може се пронаћи и у другим басмама против урока, а мотив пуцања најчешће се везује за полне органе.

${ }^{18}$ Цвета Милић наводи Негину басму против урока у потпуности: „Урок иде више пут Урочица испод пут И де се сретоше Ту се изјебоше И мојој Јелени уроци растурише." Супротстављеност урока и урочице се не темељи само на разлици у полу (дистинкција мушко - женско), већ се тиче и њиховог просторног распореда (горе - доле). У јужнословенским басмама од урока често се наилази на мотив причања о необичним догађајима, којима се извору урицања одвраћа пажња са уречене особе (Раденковић 1996: 60-61). У Негиној басми укрштање урока и урочице подразумева полни чин којим се њихова пажња одвраћа од болесника, а он бива ослобођен.
} 


\section{Преношење бајалачког знања}

Раширено је веровање да је преношење тајног знања важан моменат у животу бајалице: она не може напустити овај свет у миру ако своје знање некоме не пренесе (Раденковић 1996: 16). Све троје саговорника потврдили су да је Нега дуго тражила неког коме би пренела знање, чак и ван своје породице, али нико није показао довољно занимања и озбиљности да га преузме.

Мушки чланови колектива нису показали интересовање за учење басми. Мирољуб Савић тврди да га басме нису занимале и да је неке од њих упамтила његова мајка, док је он као дечак посматрао обредне радње из прикрајка („Сад, не знам басме. Није ме... нисмо... она шапутала. Овако знам. Баш басме нису ме занимале. То знала моја покојна мајка“).

Може се претпоставити да је један од разлога који су Савића одбијали био бајаличино шапутање. Бајање представља високо табуисану делатност, радње се морају вршити по тачно утврђеним правилима, а текст се чува у тајности (отуда шапутање) како би се осигурала његова делотворност (Раденковић 1989: 9). Басма садржи поруку упућену хтонском свету и није намењена људском уху, па бајалица шапутањем обезбеђује преношење поруке правом адресату (Раденковић 1996: 26).

Мирољуб Савић истакао је да је његова мајка усвојила нека од Негиних знања, што остаје у складу са идејом о бајалаштву као примарно женској делатности. Цвета Милић је такође записала неке од Негиних басми, а по свему судећи она није била једина која је то чинила. Ристић наводи да је још једна комшиница записивала басме:

[19] Бога ми, бре. Па, знало то, бре. Ел ти кажем? Она молила: - Ej, деца, ће ви треба то. Поготово за стоку. Пишите ово шта треба. И знам да беше покојна Цана долазила - свеску и Цана... Ова гу прича.

Цвета Милић истиче да ју је баба Нега најпре питала да ли је писмена, а да је онда од ње захтевала да басме запише. Ова тврдња сведочи о Негином страху да басме неће бити упамћене, те се захтев за записивањем јавља због потребе да се тачност текста осигура. Бајалица је можда била свесна да није пронашла прикладну наследницу и није желела да њено знање нестане након њене смрти.

Иако је породица поштовала баба Негу, женски део није био заинтересован за усвајање овог умења, делом због идеолошких опредељења, а делом и због социјалних и личних разлога. Савић је напоменуо да је једна од снаја била комунисткиња и атеисткиња, а Ристић 
наводи да је породици било тешко да се носи са великим бројем људи који је свакодневно долазио и молио за помоћ. Посете су често биле оптерећујуће, а није веровао у магијске радње и чак се противио практиковању бајања и даљем преношењу у оквиру породице:

[20] Она терала да учимо то. Ја нисам тео ... Ууу, ја сам пцувао. Нисам то веровао. Довде ми тај народ, дан - ноћ, кад ти не можеш... зовеу... да спаваш. Од народ не можеш, то нон-стоп.

Ипак, Ристић је у разговору у више наврата истицао аутентичност Негине праксе и настојао да покаже да су њене басме заиста биле делотворне и потребне заинтересованим члановима заједнице. Отуда заклињање („Бога ми, бре“), а затим и уверавање кроз реторичко питање („Ел ти кажем?“). Промена Ристићевог става може да се објасни временском удаљеношћу и носталгијом према баки и свему што је чинило свакодневицу једног прошлог времена. Његова сећања испреплитана су с осећањима поноса и нежности, али и жаљења што није придао мало више значаја знању које је Нега чувала готово читав један век, а које на крају живота ипак никоме није у потпуности пренела. Упркос томе, она је остала дубоко урезана у сећања других људи као специфична и занимљива личност.

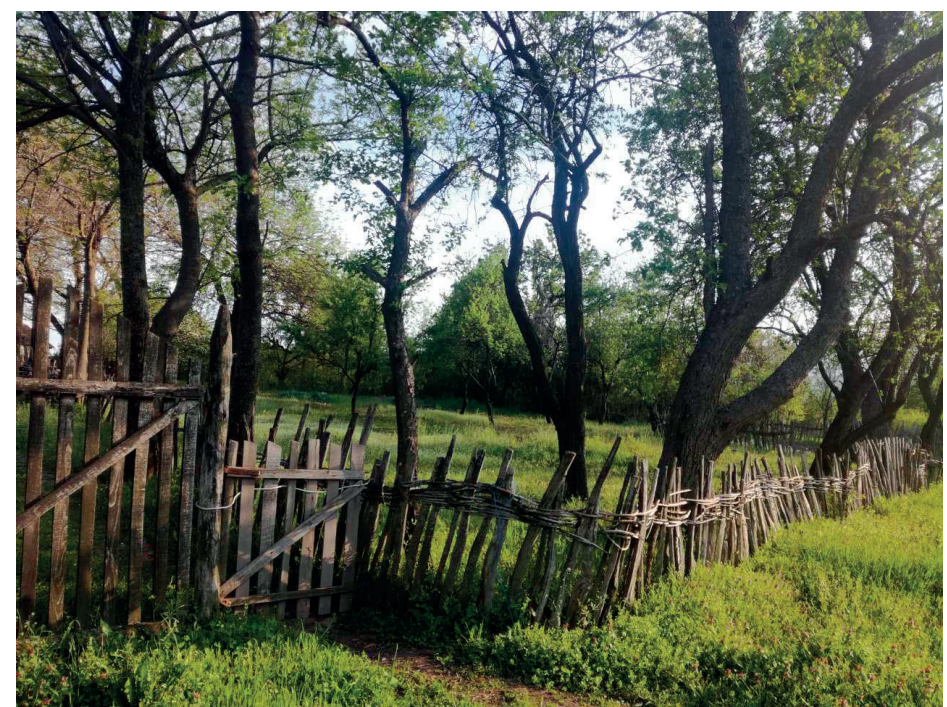

Сл. 6. Плот од прошћа у селу Рибаре 


\section{На граници између личног и колективног}

Коначно нестајање долази са заборавом. Сећање на особе које више не егзистирају на овом свету јесте један од начина да се њихов живот настави, а онај ко памти уноси у свој идентитет и део туђег идентитета. Свест о сопственом „ја“ конструише се захваљујући способности да памтимо све оно што је саставни део нашег бивствовања ${ }^{19}$, али се наша личност неоспорно формира и под утицајем онога што памтимо о другима.

Сећање на Негосаву Ристић с временом је постало део заједничког сећања, обликованог на основу низа појединачних сећања, а приче о њеној бајалачкој делатности и вештинама старији чланови заједнице преносили су на млађе генерације. На основу сећања наших саговорника донекле је реконструисан Негин живот и осветљени су аспекти њеног бајалачког знања и начини на које је користила своје вештине.

Ипак, нека од највреднијих сећања са истраживачем поделио је Негин унук Миодраг Ристић. Будући да је за Негу био везан од првих дана живота па све до зрелог животног доба, његова сећања су обојена интимнијим и носталгичним тоном, а неке од његових прича и анегдота о породичној свакодневици осветлиле су њихов присан узајамни однос. Причајући о поштовању које је према Неги гајио, присетио се и како је водио рачуна о њеном изгледу:

[21] Ја сам је бре, ја сам и нокти секо и чешљао. ... На ноге, знаш који то нокти. Старо. ... Ја је потопим и по сат времена и више у лавор, у воду, да омекне оно. ... И на руке. Да је то улицкам. Ја сам такав био, знаш? ... И овај... Имао сам то поштовање.

Носталгију за прошлим временима и нежност Ристић је показао у моментима када је говорио о предметима који су за Негом остали, као својеврсни симболи њеног присуства и након смрти. Улогу симбола сећања за њега су имали дарови које је добијала (везене кошуље, тканице и други делови народне ношње), као и трмке и пчеле, јер се Нега пасионирано бавила пчеларством.

Ристић је према даровима које је Нега годинама брижљиво чувала имао посебан однос. Након њене смрти дуго их је чувао и наставио је да их, као и она, сваког Видовдана износи у двориште и проветрава. Негина одећа постала је симбол њеног присуства:

\footnotetext{
19 „Pamćenje je izuzetno važna kognitivna sposobnost. Bez pamćenja mi bismo bili lišeni svoje prošlosti, ličnog identiteta, ne bismo znali ko smo, gde stanujemo, šta radimo, ko su ljudi oko nas, kakav je bio naš život, kakvo je bilo naše detinjstvo, školovanje, gde smo putovali itd“ (Kovačević, Trebješanin, Antonijević 2013:12).
} 
[22.1] И све сам био изнео, имале тарабе, знаш.... У двориште. Испред ону стару кућу. ... Е, на Видовдан се то... она то увек износила да се препакује, преветри и опет то све сложи. ... То, то, то ти је паре вредело.... Коко она сукње имала, коко ове, кошуље, што јој жене давале, леле! ... То је лепота, и поче ми се ствара Нега, ја то поређам.

Ристић је одећу брижљиво чувао све док није схватио да ће услед стајања пропасти. Када није успео све да раздели, одлучио је да преосталу одећу спали:

[22.2] То је све било спаковано. Давао сам, и сукње, ове тканице. ... Све сам попалио. Нико неће да узне. А жао ми.

У селу Рибаре није необично да се личне ствари, које нису спаковане уз тело покојника и на тај начин симболично послате на други свет, разделе међу ближњима, а да се оно што заостане спали. Овакво поступање има ритуалне корене, па и Ристићева одлука, иако рационално објашњења пропадањем тканина, указује на симболично опраштање од сени покојнице и слање личних предмета на онај свет, где се живот умрле наставља.

И опис Негине смрти издваја је као посебну особу. Смрт је наступила од старости, а Нега се није мучила и последње сате живота провела је певајући:

[23] Певала бре. Бога ми. - Него, дођем па: - Него, како је? Добро. Овај... - Је л' ће да певамо нешто? - Оћемо.

Лака смрт обележје је праведника и значајна је за употпуњавање Негиног лика. Миодраг Ристић је описао последње дане њеног живота са великом нежношћу, присетивши се за њега врло емотивног тренутка.

Сећања саговорника на Негосаву Ристић осветлила су не само једну особену личност и њену праксу, него и неке аспекте менталитета заједнице села Рибаре, начин живота и поимања стварности. Као централна фигура прошлих времена издвојио се лик баба Неге, познате бајалице. Теренска грађа даје увид у различите аспекте њеног магијског знања, улоге које је преузела у заједници и, с тим у вези, однос заједнице према њој и традиционалној магији у ширем смислу.

Поља Негиног деловања ширила су се и умрежавала, почевши од бајалачких знања, као превасходно магијске сфере, па све до видарских способности, попут употребе лековитог биља, акушерства, ветеринарских захвата и намештања удова, што указује на сложеност њеног позива. Позиција бајалице у патријархално-руралној заједници 
указује се као специфична - жене бајалице и видарице долазиле су до својих позиција и успињале се на хијерархијској лествици колектива управо захваљујући својој пракси, која није само подразумевала магијско знање и видове медицинског и ветеринарског знања, већ је почивала и на ауторитету везаном за старосну доб, религиозност, као и на поверењу и поштовању.

Женски чланови колектива показивали су приснији однос према бајалици и њеној пракси, вољу да и сами усвоје нека од магијских знања и строже поштовање табуисаних радњи, док су мушки чланови били спремнији да прекрше табу и обред извргну шали. Временска дистанцираност од готово пола века условила је постојање амбивалентних ставова саговорника о народној медицини и бајалаштву.

Чланови заједнице веровали су у бајаличине магијске моћи и начине лечења и у највећем броју случајева показивали велико поверење у традиционалне приступе. Савремена медицина и стручни лекари, иако приступачни, дуго нису у потпуности прихватани међу становништвом патријархално-руралне средине Рибара. Навике мештана споро су се мењале, а поверење у нове приступе стицало се постепено.

У раду је испитан и однос између појединачног и заједничког сећања и начин на који се сећања појединаца умрежавају. Заједничко памћење није пуки збир појединачних сећања, већ тачка њиховог уланчавања и преплитања. Сваки од саговорника дао је специфичан осврт на минула времена и једну личност, али тек заједно њихова сећања испрела су делове приче о заједници која више не постоји и баба Неги, као симболу једног времена и погледа на свет. Говорећи о особеностима колективног памћења, Куљић истиче: „Slično pojedinačnom, i kolektivno pamćenje je organizovano po obrascu perspektive. S obzirom na strukturu, ne čine ga celine, već mozaik izabranih sadržaja. Biraju se sadržaji od značaja za opstanak i integraciju grupe“ (Kuljić 2006: 51). Heгина појава означена је као веома специфична код све троје саговорника, а она је, као носилац једног прошлог и за млађе генерације далеког времена, одабрана да буде актер прича које на најбољи начин илуструју преношење сећања о колективу и начину живота који више не постоји.

\section{Библиографија}

Дивац, Зорица (2003). Врачање у североисточној Србији. У: Д. Радојчић (ур.), Традиционално и савремено у култури Срба. Посебна издања 49. Београд: Етнографски институт САНУ, 111-121. 
Ђорђевић, Смиљана (2008). Магијски текст бајања: између вербалног табуа и фолклоризма. У: Н. Љубинковић, С. Самарџија (ур.). Српско усмено стваралаштво. Београд: Институт за књижевност и уметност, 389-430.

Ђорђевић, Смиљана (2011). Приче о (успешним) излечењима: Оквири говорног жанра. У: М. Детелић, С. Самарџија (ур.). Жива реч. Зборник у част проф. др Наде Милошевић-Ђорђевић. Београд: Балканолошки институт САНУ, 165-189.

Ђорђевић, Тихомир (1938). Зле очи у веровању Јужних Словена. Српски етнографски зборник LIII. Живот и обичаји народни 23. Београд: САH.

Илић, Марија (2005). Тајно знање: Бог ми то дароваја. У: Б. Сикимић (ур.). Живот у енклави. Лицеум 9. Крагујевац: Центар за научна истраживања САНУ и Универзитета у Крагујевцу, 221-242.

Раденковић, Љубинко (1996). Народна бајања код Јужних Словена. Београд, Ниш: Балканолошки институт САНУ, Просвета.

Раденковић, Љубинко (1996а). Симболика света у народној магији Јужних Словена. Београд, Ниш: Балканолошки институт САНУ, Просвета.

СMP: Кулишић, Шпиро, Петар Ж. Петровић и Никола Пантелић (1970). Српски митолошки речник. Београд: Нолит.

Blum-Kulka, Shoshana (1993). You Gotta Know how to Tell the Story: Telling, Tales and Tellers in American and Israeli Narrative Events at Dinner. Language in society 22(3), 361-402. Преузето ca: http:www.jstor.orgstable4168450, приступљено: 16. 3. 2020.

Bošković Stuli, Maja (1975). Usmena književnost kao umjetnost riječi, Zagreb: Mladost.

Brenko, Aida (2004). Praktičari narodne medicine. Sociologija i prostor 42(3-4) (165-166), 309-338. Преузето ca: https:hrcak.srce.hr34555, приступљено: 16. 3. 2020.

Ilić, Marija (2007). A Shift in Ethics: The Serb-Albanian Conflict in the Vernacular Discourse of a Conjurer from Kosovo. Zeitschrift für Balkanologie 43(2), 145-167.

Isić, Momčilo (2008). Seljanka u Srbiji u prvoj polovini 20. veka. Beograd: Helsinški odbor za ljudska prava u Srbiji. Преузето ca: https:www.helsinki.org.rsserbiandocOgledi09.pdf, приступљено 16. 3. 2020.

Kerewsky-Halpern, Barbara (1985). Trust, talk and touch in Balkan healing. Social Science \& Medicine 21(3), 319-325.

Kovačević, Ivan, Žarko Trebješanin i Dragana Antonijević (2013). Teorijsko-pojmovni okvir za proučavanje nostalgije. Antropologija 13(3), 9-26. Преузето ca: http:www.anthroserbia.orgContentPDFArticles71ca98e5debf4f8080eb2809c50fc400.pdf, приступљено 16. 3. 2020.

Kuljić, Todor (2006). Kultura sećanja. Beograd: Čigoja štampa.

Petrović, Sonja (2018). Charmers on the Folk Practice of Charming in Serbia. Incantatio 7, 131-159. Преузето са: https:ojs.folklore.eeincantatioarticleview72114, приступљено 16. 3. 2020.

Radulović, Lidija (2009). Pol, rod i religija. Konstrukcija roda u narodnoj religiji Srba. Beograd: Čigoja štampa.

Vivod, Maria (2014). Radmila - the Fairy-clairvoyant. Rethinking Ethnopsychiatry a Case Study from Serbia. Journal of Medical Anthropology 37, 8-17. 


\section{Прилози}

[1] Миодраг Ристић: Не може гу [баба Неги] оправе траг. Овај кад се рађао, па, дабоме, Малиша, прнашли гу, она отишла у Зебицу, не мог... он у Зебицу ноћу, она у Николићи гу одвели, знаш. Па, то сваку ноћ, то драње, то довде!

Ана Савић: И сваки, сваки дан долази неко?

М. Р.: Па, кад буде за крмила уочи Ђурђевдан, брање трава, оно, и Зебица, и Крушинце, и Срндаље, и Рибаре, и ово, Зубовац жене, с оно, с она крмила за стоку.

А. С.: А она позове тако и они дођу заједно с њом да беру биље? Шта раде?

М. Р.: Шта? Па, дође да ги прави крмила за стоку. Знаш. Сас оне травке, донесу. Трице и оно. Уочи Ђурђевдан.

А. С.: А чекај, шта се ради с тим крмилима после?

М. Р.: Па, за краве, за овце, шта знам. То правила.

А. С.: То да напредује стока?

М. Р.: Аха. Да, да прича овај: - Бежи, реко, Милосава! - Ево ти. Донела, оно тачно крв у флашицу. А знаш које краве горе, ово? И после је донела, овај, кошуљу ону вежену и још не знам шта. - Да ми није била... Реко, бре... - Богами, нема. Е, сам ти показала у ову флашицу шта сам музла од краве? И Нега гу правила.

А. С.: А шта?

М. Р.: И чујем де гу прича, узнеш јаје, и како треба се баје... па, га из... од рогови, ово. Па, тамо позади, да га сломи, знаш, низ кичму, па, да баци. Ал прича гу како треба, шта да каже. Онда, овај, кој ти обрао... да л' беше три главице бели лука и паприка, ово-оно се меша у оно трице, она то набаје. И то да ујутро рано, пре сунце, накрми краве.

А. С.: А, чекај, а то кад намузе крв уместо млеко из краве?

М. Р.: Па, да. То учињено, значи бави се то ови што знају, ови као, ово сад, ове магије. Тако има људи то...

А. С.: А она то скидала?

М. Р.: Она то скидала.

А. С.: А кажи ми је л' она... Одакле она родом била?

М. Р.: Из Зубовац.

А. С.: А донела то знање отуда?

M. Р.: Па, оно шта знам, каква је, ово, ја прошли пут питујем: - Je ли, бре, у колико године си се ти удала? Знаш, је л' овај, Света [баба Негин син] био 1903. Не могу да дођем, кад она нема ништа од документа. - Јеси стара била? Јеси остала одма ил неси трудна? Тако сам је испитувао да би сазнали за године. И... броји и каже - сто три године. И беше ме терала: - Еј, ајде погледај ми ушта, да видим да л' ми ницау 
жуби. - Бежи, реко, бре, да ти ја гледам. И ја реко да питам. А покојни Гане: - Лаже, виче, Нега, она је старија, више има. Јер она довела Ганета, Гане из Љуптен, био ковач ту, сас ону Лепосаву га оженила. Је л' та Лепосава Рогоњка, она из Рибаре била. Била горе она кућа, она преко реку.

[2] М. С.: Занимљивија је била баба Нега, њена ујна. Она је звала ујна, не знам шта су. Кад су код нас Задушнице, онда оне деле, на други дан Задушница баба Нега донесе код моје баба Живане неку храну, баба Живана носи код ње. Али, баба Нега је мене породила, односно, кад сам се ја родио, она је била бабица. И, баба Нега је била наш надрилекар, односно видар. Није она била надрилекар, она је имала једно много велико знање. Она је све нас лечила и сву децу у комшилуку је она породила. Мене исто. Рекла ми да сам рођен деветог маја, родио сам се у један сат у подне. - У велику шобу сам те породила. Еее, ти ши ше родио у шред подне. Микуло ме звала. И нико није тео да је слуша. Баба је живела сто три године. Не, живела је... сто три је уписано на споменику, а живела је сто седам. Умрла је од старости. Баба била много специфична, то је једна личност коју зна цела Рибарска Бања и сви су је поштовали. Иначе, знала је да лечи свим травама и све траве је скупљала.

[3] М. С.: Ал' да ти причам, баба Нега се бавила абортусима. И долазе жене да их абортира. И сад, њен унук Миле, он старији, а она то ради у подрум, па, кад дође нека жена, она је савије на дрвено корито. И она то с неком, чиме она то ради, неко вретено, неке муке, то је страшно болно. Али то ове што се курвају, сељанке, оне дођу ил неће да чувају више децу, шта знам. И она то радила врло успешно. Али јој се десило једанпут да је нека жена добила тровање и заглавила у боницу. Дошла полиција, Дрндаревић неки: - Ајде, бабо. Водили они њу, испитивали је. Исприча она како је било и пустили је, ништа није било тој жени. И запретили њој да то више не ради. Али, пошто није било гинеколога, баба порађала сваку жену, али сваку. Ђунис, Каоник, Шиљеговац, Зебица, Гревци, Рибаре, Зубовац, Росица, Бољевац, Рлица и Срндаље. Али сваку од моје генерације. Значи, свако дете до пре дватридесет година које се родило, она га је породила. Значи, то се знало, она је била гинеколог. Сваку краву истелила, свако теле, сваку овцу, сваку свињу и сваког је излечила. Чак од уједа змије имала неку, неку, неку траву, неку белу боцу, па је лист од те беле боце... То никад више у животу нисам видео. Де пчеле, то могло ту да расте, у њен пчеларник, она имала трмке, није кошнице. Чувала пчеле баба и ми: - Шта ти је то, баба Него? Ја сам је слушао, па нам она прича. Она је тела да прича: - Микуло, дођи да ти кажем, неће ме шлуша ова Вукошава, шнаа, 
ништа не зна. И Милица ништа не зна. Ће помру, ће забораве, нема куј да памти, то шам научила од моу покојну мајку. Ја: - Шта ти је то, баба Него? - Виш ову траву? Виш да она, ишта ти је као жмија шарка на грбину шарена. Е, то кад те жмија ује, иштучаш одма и туриш на рану и шве отров ижвуче. Можеш и да ишпијеш, ко ти ждрави жуби. Ал то ижвуче отров, то много добра трава. Никад је више нисам видео, значи, та трава не постоји.

[4] А. С.: А си је возио некад негде, да иде она код некога да лечи или негде?

М. Р.: Ма, долазили они.

А. С.: А долазили?

М. Р.: Долазили по њума бре! Ма, све бре. Једно се порађа, једно...

Добрила: Тури у кола и возе гу... иде

М. Р.: Не, не, после кад сам купио кола, то, по ти свеци да је возим и у цркву и горе у бању на купање.

А. С.: Мхм. А у бању кад је одвезеш?

М. Р.: Па, беше клела овога попа Жику и ово. Затекла их на Велики... возио сам је у бању, па после иде на причес, Велики петак, у цркву. И однела увек она, за код попа, то је поштовање, и однела, овај, да да Мици, звала се та попадија Мица. Она је од чувени ти Марићи из Росицу, узела тога што је био поп, поп Жика. И затекне де пржи месо. Јао боже, кад је...

Д.: Поп? Попадија ел поп?

М. Р.: Попадија на Велики петак, то пос велики. Није мало клела Нега. Дабогда јој последње, па она, она... Затекла де... јер народ пре, знаш кад се оставља водица за славе и ово... Или за Тројице кад буду, ови свеци, за Ускрс, сви дају. Кој нема паре, он даје јаја, пасуљ, пшеницу, имао онај само што носи, један иде с попа, вешаљке месо, гомила натовари...

Д.: Крошњу носи и то дава, дава - узима.

М. Р.: И онија бисази, знаш?

Д.: Ил бисази...

М. Р.: Што се ставља, и овде, и позади. После изашли онија ранци.

Д.: То има још у Зајчар, тамо у села.

М. Р.: Јебем ли ти... И ова није мало исклела, покојна Нега. Јао мајко...

[5] М. С.: Иначе, знала је да лечи свим травама и све траве је скупљала. Ја се сећам, кад буде Ђурђевдан, на други дан Ђурђевдана, или беше један дан испред Ђурђевог дана, не могу да се сетим, нико неће бабу да слуша. Она има пун ковчег, то је једна шкриња велика са тим сувим травама. Лечила она екфикасно жутицу, лечила. Жутицу, за 
жутицу се иде у болницу, а баба је то лечила травама као руком овако. Мене уједе неко куче на трешњу, па ми нога се надује оволика. Ујело куче дудињке, па ми то загнојило, ја не смем, Стојана ће да ме убије.

А. С.: То мајка?

M. С.: Не могу да устанем... Моја мајка. Из кревета. Сад сам прешо на неку другу причу, а после ћу да причам о травама шта је баба Нега знала. Али смо ишли да крадемо трешње, ја и неки мој друг, Драгиша. И ја док да се, ранке, неке оно, ђурђевке, како се зову, не знам, увече. И ја да сиђем са трешње, оно дошо пас. А то је био, било једно крволочно куче. Ја да побегнем и он ме стиже, шћапи ме за, за, за бутину, уједе ме и ја сам носио гумене опанке у то време, и док сам ја прескочио ограду и скочио на пут, био макадам, није био асфалт, мени пун опанак крви. Ја дођем кући и неко марамче нађем, Стојанино, од моје мајке. Скинем панталоне и то завежем, замотам. Ту су биле, овако, две рупе, две одоздо, како ме куче уватило за... или четри, не могу да се сетим. Међутим, куче јело дудињке, па оно како јело, цела једна дудињка остала у ону рану. Ваљда му то било у чељустима, на зубима, где ли, немам појма како се то десило. Ја нисам ујутру устао због бола, него, као, не могу, нешто ми фали, трте - мрте, ово - оно. Па, још један дан прележим и мени ти се нога надује као дирек. Стојана дође: - Ајде, бог те убио, пушти овце, треба д' и'еш у школу. Дере се, ће ме бије. Која школа, које овце?! Ја не могу да мрднем! Ја устанем, види она да нешто озби...: Шта је било? Ја мора да признам. Кажем: - Бре, овима у Злате, тамо, Драгошљевима, тако се они звали, био сам на трешњу, ујео ме пас, Драгиша ме водио. Кад она погледа, ће да ме бије, кад она виде, мени нога оволика. Отрча она код баба Неге. Дође ти баба Нега: - Шта је било, Микуло? Ја ништа, шта је било, шта да кажем. - Шкини панталоне да видим. Кад виде: - Ша ћу ја то да ти ижлечим. Донеши, је л' имате ш... неке траве, по градинче, тамо начупа, оде кући, донесе нешто из ковчега неку суву траву и сумпор. Знаш шта је сумпор?

А. С.: Да, да.

M. С.: И стави ти маст и стави то да се кува у чорбалук један, на шпорет. Црни онај шпорет на дрва. Заложи баба шпорет, стави да се то кува, меша, меша: - Ша ћу ти ја направим мелем, за три дана ће ти прође, немо се шекираш, није то ништа. Направи она неку муку, а мени само нешто сева, само сева. Гној из оне... одвише ме, и оно где зубе заронило у месо, оно цури гној и отуд дудињке, семенке од, од дутке, из ону рану излазе. То загнојило, овако дебело. Она то мени препра с неку млаку воду, неке крпе, тамо пра, кува нешто, некакву дезинфекцију, баба не знам шта му ради око онај шпорет. Напуни оне ране са оним мелемом од сумпора. Знам да је сумпор био главна ствар и много неких трава. Напуни то, завеза. За три дана је то спласнуло, 
ја мало, по мало проходах - ево, и дан-данас имам ожиљке ту, а од тад има четрдесет, как, педесет година. Пуних педесет година има како се то догодило и никад ми ништа није било.

[6] А. С.: А је л' знаш нешто, нешто рецимо за врачарице и то? Неку бајалицу или нешто да се сећаш да си некад нешто...

Цвета Милић: Па, знам, ал то је млого безобразно.

А. С.: Па, нема везе, ако је безобразно. Причај слободно.

Ц. М.: Ја сам Ј. бајала. Она зна, Ј.

А. С.: И како си...?

Ц. М.: Урочили је тамо у Рибаре. Возила кола и отишла. Бабе седу, каже, неке уз осталче, поседале. А нису је виделе дуго, па оне бабе је гледале, па је урочиле. И она дође: - Јоо, каже, бабо, мене урочише! Реко: - Како те урочише? - Тако. Бај ми, бабо, нешто. Ја ћу да јој бајем. Па, сад С. ту, ако је ту. И ја јој бајем.

А. С.: Причај, ајде, нема везе.

Ц. М.: Реко: - Ј., ја морам да ти пребајем, то је безобразно, ал' ја морам.

Урочица иде испод пут

Урок иде више пут.

И... Урок иде више пут,

Урочица испод пут.

И де се сретоше,

Ту се изјебоше.

И мојој Ј. уроци растурише.

Она се смеје, ја се смејем. Смеј, смеј. И тако ми басма било и помогло јој, питај је.

А. С.: Аха. А шта, како се осећа особа која је урочена? Шта јој, шта јој се деси? Је л' јој није добро или?

Ј.: У очи.

Ц. М.: У очи, каже. Очи јој...

J.: Температура.

Ц. М.: Температура у лице, у очи. - Иии јоо, бабо, иии јоо, не могу! И ја јој то безобразно из...

J.: Не може очи да се отворе.

Ц. М.: Да. То јој бајем. - Па, бабо, тако се не баје. Моа мајка другше баје. Реко: - Ej, ја не знам. Ја тако знам, баба Нега тако бајала.

А. С.: Аха, ти си од баба Неге научила?

Ц. М.: Од баба Негу то сам чула.

A. C.: A се сећаш још нешто то да од њу памтиш, да је нешто бајала ил да је неке враџбине правила да си видела ил да је неко причао за њу? 
Ц. М.: Па, причали за њу потпасувала жене да остану трудне. Стомак ги потпасувала с тканице. Потпаше ги баба Нега и оне остану трудне. И порађала жене.

А. С.: Сама све?

Ц. М.: Сама баба Нега. Кад било за мене да родим Лелу, ја нећу да идем у Крушевац. Ишла сам четири-пет пут, Ано. Било ми тешко. И терали ме четири-пет пут, по болнице сам лежала. И кад беше да се породим, кад да се породим мене се не иде у болницу. Ћу терам да доведеу баба Негу горе куд стару кућу да ме баба Нега порађа. И баба Нега дође, узе ме баба Нега. С Милицу и с моју свекрву на једну чергу, на једно ћебе, па ће љуљав, љуљав, лако ћу се породим. Де... не могу, ја сам примала инекције, одржавала сам трудноћу. Де се мог породим без лекари. И баба Нега сву ноћ ме порађа и деда то чуо, деда Станко, па кад наиђе. Па, кад викну на њи: - Еј, ако на ту жену шта фали, ако умре жена ил то дете се не роди живо, ја ћу све вас у робију да ве отерам! И баба Нега престаде. Неће баба Нега да ме порађа. Ал вика баба Нега: - Мушко ће да роди, мушко, свети Лукан, крупан! Кад ја отидо у Крушевац, ја после, породише ме, ја тражи мушко дете. А породише ме у Крушевац чим отидо, одвезоше ме с кола. Богдан јурну...

А. С.: А ти женско родила?

Ц. М.: А оно женско, а баба Нега вика свети Лукан! Каки Лукан! Свети Лука било.

А. С.: Колко године она имала тад? Она стара била много кажу.

Ц. М.: Баба Нега млого године имала, млого.

А. С.: А не знаш још тако нешто да је бајала?

Ц. М.: Она сто пет године живела, баба Нега, Милина баба. Сто пет године имала.

А. С.: Па, знам, била позната у цео крај овде.

Ц. М.: Бајала, бајала и на стоку, на краве. Бајала на децу.

А. С.: А то да иде напредак? Да има стока, да се...?

Ц. М.: Бајала све, све знала. Да има стока млеко, да... све. И мене терала.

А. С.: Да научиш?

Ц. М.: Да научим. - Јеси писмена? Реко: - Писмена. - Е, ајде ти пиши, а ја ћу ти причам. Ће ми она прича, а ја да пишем. И полази с мене до онај бандер онде, ће дође куд нашу кућу да ми прича. А Вукосава и Милица, знаш. Ће се наљуту оне. - Баба Него, врати се. Ће се наљуту Вукосава и...

А. С.: А то је снајка и...?

Ц. М.: Дабоме, снаа и унука Милица, Милина жена. Милицу знаш. Ће се наљуте, знаш. - Немој, баба Него, да идеш. - Па, ће ми даш лецка ракију да пијем, Поточарке, ти! Је л' знаш? Ми смо из Поток. - Ће ми 
даш мало ракију да пијем и да напишеш све што ти ја причам, ти напиши. И тако, после ће да знаш. И ја не тедо ће се наљуту ови.

А. С.: Аха. Што тела теби да остави знање, а није њима?

Ц. М.: Тела да ми остави знање, тела.

A.C: Па, је л’ се сећаш нешто још тако да... те травке рецимо што знам да правила неки мелеми, да... да л' памтиш то или...?

Ц. М.: Е, не знам.

А. С.: Не знаш?

Ц. М.: Не знам стварно.

А. С.: Или још неку басму да знаш да је...?

Ц. М.: Па, ето знам ту басму. Млого лепа басма. То видиш. Јелена зна, бајала сам јој. И било јој добро.

[7] М. Р.: А покојни Драгомирче, овај из Гревце, Бинин, овај де мој шурак на призетство отишо, покојни Светомир. Бе... бемо правили обори и њега није мрзело... ја несам... не знам де сам радио. У задругу, де ли сам био? Не могу се сетим де сам био. Бранко у бању, покојна Вукосава у њиву, она... каже жене рој долазе код... нон-стоп. А овога није мрзело да се, овај враг, скине, ово, од обор, знаш... покривао са ћеремиду цреп, онај стари обори. И њега није мрзело, него скине се, а он спадало био. То је био спадало човек. И дотрчи поред кућу и код басамак чучне, склони се. А ова у ходник... отворена, топло време. И то бацала жарчићи и то бајање и...

А. С.: Аха. А он гледа?

M. Р.: А он слушао, није, да се не појави. А после ми исприча: $-\mathrm{Ej}$, све сам чуо! Јао, мајко мила! Па, то ти шокови.

[8] М. Р.: Али знаш кад је умрла колико... Да су чули? Него несмо јављали. Па, то не би могло да примимо... да стане у ово. Кад је толико ово. Па, знаш кад беше она, беше... бе ја кречио, а она ће да иде: Ајде да ме одвезеш у Рибаре. - Па, шта реко стално ми изналазиш... и измишљаш реко сад. Данас сам слободан, да порадим нешто, кречио сам. Да ме... да гу возим код ћерку. Па, реко стално... навади се, изналази... Иди како знаш, имаш аутобус, чекај, па иди. И ја сам кречио и долази Раде с бициклу: - Ајде, бре, каже, Нега умрела! - Шта ти је бре? - Ајде, остављај то, умрела. - Како умрела? Кад ово... то је било да л' беше седмадесете ил седамдес прве године. - Па, де умрела? - Па, у Рибаре. Ајде. А он, Раде радио у задругу. И неко каже. А бре, каже, Нега умрела. Брзо ја, баци оно. А само што сам купио фићу. Брзо ја, реко, стави ту бициклу, идемо, овај, с кола. Горе у Рибаре улете. Пијац био, млого народ, пијачан дан, недеља: - Де је Нега? - Ено, каже, одвезли је за Бању. Оно Муја покојни радио у кланицу у... помагао, уводио, дабоме, кад се кољу... Кланица рибарска радила нон-стоп. Кој зна колко 
се клало и снабдевао Крушевац сас месо. Каже у Бању је неки колима одвезо. Жене кукају... а то је кад се пође према овај... Сава Лазовић како ти кажем... па она кућа де је сад продавница што држи овај... ту је Бена држао Крушевац промет, па је овај сад Шваба...

Милана: Знам, знам, знам Крушевац промет био.

М. Р.: Сад Шваба држи ову продавницу. Она уз тарабе ту. Како био пијац... сад де е прекопута Беришљеву продавницу, ово, оно, де је она... И ту је некад била држ... била продавница. Ту има оно дрво. А ту био Софроније из Шљиговац. Садолеџија. Сладолед. И он јој да бре... А она... Исто за децу и на ону жену... Он толико то имао поштовање. Уууу бре! Колко пут и долазио овде. Код нас, Софроније.

М.: И он јој да сладолед?

М. Р.: И он јој да. Наишла она, дошла: - Eј, баба Него, ајде овамо. Дао јој онај сладолед она вероватно...

Милана: Била врућа.

М. Р.: Била врућа. И онај... а ладан сладолед. И пошла за, за горе, за код ћерку, у Лазићи и - дринг!

М.: Падне?

М. Р.: Падне, значи, вероватно је жигнуло оно од хладноћу. Знаш?

М.: А стара...

М. Р.: А стара. И то, и уз тарабе... и жене... ту, народ се прикупио. Жене каже кукање и бијење у главу за Негу. Свеће испопаљене. Одма ту продавнице, знаш. Упалили свеће. Неки... а? Мује неки реко: - A, бре, каже, Нега умрела. Муја дотрчи како био у кланицу онако: - Кад бре, каже, умрела? Де бре? - Горе каже, испод продавницу, код Савине... тај Сава Лазовић. Код Савине, бре, куће...

М.: Виш да ју терало...

М. Р.: И Муја излети из кланицу с... онако умазан, с оно радно одело. Дотрчи, погледа - Нега уз тарабе. Он притисни, пипни... Нега врућа. Муја удари гу масажу - динге, динге, динге. Тек, баба прогледала.

А. С.: Аха? Повратио је?

М. Р.: Повратио је. Не знам кој... Биве из Јаковље био сас комби. Знаш онај матрапаз сас стоку. Биве, знаш? Добривоје, па га Биве...

Добрила: Добривоје, Биве.

М. Р.: Биве ово, брзо - одвезли је за Бању. Ја с кола, питам у Рибаpe, кажу одвежена за бању. Жива је, ал, каже, одвежена горе. Како сам ја улетео у круг.. јао, каквом сам брзином... И де ћу је нађем - у вилу Србију, у ово, у амбуланту.

М.: А жива?

М. Р.: Освестили. Жива.

М.: Седи?

М. Р.: Жива. Сестре, доктор. 
М.: Тачно од сладолед, де оно ладно.

М. Р.: Дабоме, овај гу... А после ми се.... - Види, виче, Драги ме повратио. Дабогда...Шта ме поврати? Д'идем слатко да се одморим... моје старе коске. А он кад гу масирао, оно гу све кожу, познава се, знаш...

A. С.: Јао...

М. Р.: И сад да видиш штос. Натоварим ја [...] Па, Мића милицајац виче: - Леба ти јебем, па како си улетео, шта се... како си улетео, виче, којом брзином у круг бањски. Баба је била у питању. То он видео, знаш? То се брзо рашчуло шта се десило. И ја бабу натоварим и сад да видиш шок. Станем ја за Дарину, за ћерку: - Ајде реко, баба бре, тако и тако. А неки већ обавестио њу: - Па, де је? Реко: - Еве гу у кола. Ајде, реко, седај овде. Бабу ја позади наместим. И сад види ово. Док сам ја то, док та драма се одигрувала, све растребена соба. Покојна Драгица, покојна Драгица, Цана, да л' беше Милосија, још не знам кој. Скупило се ту, све то растребено, жене...

А. С.: Чекају?

М. Р.: И сад кад ја долазим, они на капију. Дочекују.

Д.: Чекају, дочекују.

М. Р.: И кукууу, кукау они... А ја нећу да станем, него... знаш, сад је направљено... Сећаш се пре какво ми двориште било до стару ку...? Ја долазим, ово. Оне седеу на капију.

Д.: Кукају?

М. Р.: Дочек, дочекују Негу - умрела Нега. Ииијао! Не знам сад. Ијао ово. Ја кад се сетим, Драгица: - Ијао, бабо, и куку, бабо! А ове? Јао, боже кој је то циркус. Излази Дарина, ја преклапам оно седиште. Једана само врата. Тако е на фићу.

М.: Знам знам. Фића.

М. Р.: Извукујем... Кад видоше Негу, оне изпопадаше. Жива Нега. Џабе ти оно! Јао боже! Јао мајко! Кој је то хумор био! А кој дочек, кукање! То све. А у Рибаре исто. И реко... а после реко, еј колико гу жене жалиле. Па, свакем пружила помоћ. Која би то, реко, то би земља...

М.: Ал ове. Мог да замислим кад чекају.

М. Р.: Чекају, дочекују

Д.: И растребују све, је ли?

М. Р.: Све се наређале, ки оно кад дочекујеш некога.

М.: Сватови.

М. Р.: И она... јао мајко!

Д.: Таман да не дочекау бабу...

M. P.: A ја нећу станем да им кажем. Ћутим. Него, онамо стадам, излази Дарина, њена покојна ћерка. Ја изађо с ове стране. Преламам оно седиште: - Ајде реко, Него. Кад изађе Нега... И куку мене! Ове да испопадају. Жива Нега. Јао, мајко мила! И после живела она. 
[9] M. С.: То зна да уради и шта је знала још да ради? Ааа, ко нема децу. Она је знала да лечи стерилитет. Али га лечила на неки такав начин безвезан да то није нормално, шта она дала да поједу и да попију, ја не знам. Од свих тих силних трава је давала свашта. Али, ја се сећам, био сам дете, па имао сам десет година. Значи, сад има шездесет година и седам месеци, значи, пре педесет година. Можеш да схватиш колико је народ био глуп пре педесет година? Дође ти неки сељак, за мене то био много стар човек, ја сад носим фармерице, вунене кошуље, ја јесам за њега дечко. Толико ми био стар - шубара, бркови, необријан, гуњче, чакшире, свињски опанци. Преко планине с неке... такамче, кола и краве са запрегом. Жена шамију, није марамче, него знаш шта је шамија? Шамија, оно ко што носе Шиптарке, то мож да видиш у овој серији, па и они не носе шамију више. Моја баба носила шамију и врзоглавче. И фес! И био црвени фес, па неко врзоглавче, с тим веже косу, то се тако звало. А шамија, то се забради, па се веже одозго на вр главу. Како да ти неко види лице, човече? То је било више турска верзија. Е, сад тај брачни пар дошо, нису имали децу. А пошто сам ја одрастао у њиховом дворишту, ја ни отуда нисам никад излазио. И тамо смо се скупљали сва деца. Било нас десетак, десеторо деце и тамо се играмо. Пошто сам ја једино мушко дете одавде, брат био у школу у Ниш, ја где ћу, него тамо.

А. С.: То код баба Неге у дворишту?

М. С.: Код баба Неге, аха. И, сад, а њена снаја Вукосава је била, па атеиста. Баба, исто баба стара, али није веровала у ништа. И страшно је нервирала, то је била њена снаја, удата за њеног сина, Бранка. Он био кувар у Бању, неписмен, али је био кувар. Био шеф кујне. Умро, бог душу да му прости. Рођен деветсто дванаесте године. И старији Света, Света, рођен деветсто треће, умро и он. А, баба живела сто седам година. То је чудо од бабе. И, сад, ми се скупимо, сви је куде: - Е, види је, са ће да излаже ови нешто. Шта зна она, не зна ништа! Међутим, она је све знала. Е, сад, сами тај начин, то је и личило да не зна ништа. Сад она њих прегледа тамо. Ону госпођу, ту сељанку подиже подвеже је са неким тканицама, подиже јој стомак, шта јој ради тамо, не знам, враћа јој материцу, неке муке ради. Ономе госп... младожењи нешто даје да пије, неке травке. Али, сад! Шта је ту у тој, у целој тој причи смешно и, и несхватљиво, што никад нико од нас није знао какве везе има. Она је остала у другом стању и родила дете и баба је добила поклон идуће године. Али, она њима каже, сад та кола и краве, да оду доле на сокак, па да расточе, имаш предња кола и задња, да изваде клин и да раздвоје кола, испрегну краве. И, сад, ту они мора да се воле, да праве дете. Знаш? Па, кад споје кола и ударе клин, то ће да се закачи, она ће остане у другом стању. Али им је она дала и милион трава да поједу 
и попију и бајала, врачкала, триста чуда, а то мора да ураде на раскрсницу. А пошто нема друге раскрснице, била доле раскрсница, код ове наше бандере. Али, у то време нису били аутомобили, био макадам пут. Нико није пролазио. Мого си да седиш ваздан, нигде никог нема. Е, они то треба да ураде тамо, а сад, нико сад, ми, то је било једно друго време, сад би свако ишо да каже: - Марш, бре, пичка ви материна, шта то радите ту! У то време нико неће да изађе, па то срамота! Све се то закључало по кућама и сви гвире, гвире кроз прозор, шта се то ради. И они то раде тамо на раскрсници. Е, после прошло неко време, та сељнка је затруднела и родила неко дете и они су долазили, они бабу побратиме, свако је говорио: - Дабогда, бабо, да живиш сто година! Она живела сто седам! Свако ко је дошо: - Дабогда, бабо, сто година, дабогда сто година. Нема коме није помогла. Чак, беше управница Деса у Рибарску Бању, то исто нека комунистичка управница била. Она је била наредила, кад дође баба Нега, бесплатно купање у амам, турско купатило. Ово што смо ми сад направили велнес центар. У то време је то радило, радио један зубар тамо, деловао и биле оне каде, кабине, мож да се купаш. Баба оде, никад јој ниједан није наплатио карту. Прорадио аутобус био, ишо једанпут дневно. Сви су је возили бесплатно и имала је да се купа бесплатно у Рибарској Бањи и да се врати. Иначе, да скратим причу о њој има много, много, много прича, она, не знам коме, никаво зло није... Један једини случај, то био због тог абортуса, водила је полиција. Нека жена тела да добије тровање. Иначе, све је што је радила, урадила успешно и сропроцентно. Значи, ништа није погрешила! Ништа, све нас је лечила, жутицу, ми се заразимо, пијемо свакакву воду, она то направи неки мелем. Каква твоа болница од жутицу, то нема ни појма!

[10] М. С.: И, баба, сећам се ја, затели се њима крава, отели се и изручи се, испадне крави материца, крава легла, а Брана ветеринар, доктор. Беше исто оно комунистичко време, па то има триес година. Ма, четрдесет можда има. Стара штала, калдрма доле. Она се крава изручила, она пометина, крв, испало оно све, материца, они оно теле узели. Знаш, крава неће да устане. Бана псује, ладну воду, пере оно, покушава да врати оно у ону краву. А она дошла с једно тојаче, била стара, она тад имала деведесет година, сигурно. Па, лупа у калдрму, тап, тап, тап: - Добар дан, доктуре! Она га виче доктуре. Он ништа, она опет, чук, чук, чук: - Добар дан, доктуре, поможи бог, доктуре. Он: - Бежи, бабо, у пичку материну! - Доктуре, то ше не ради тако. Мене боле руке, ја не могу. Шлушај да ти кажем... - Шта знаш ти, бабо?! Која је ова баба? - Па, то баба Нега. - Ти си та баба Нега! - Ја шам баба Нега, то моа кућа, мој унук офичир, дабогда и ти да имаш тако! Чекај да ти 
кажем... - Шта ће ми кажеш, бабо? - Ужни врућу воду, па опери ти шламу и ужни маш, па намажи то, па, па доведи куче да лане на краву да ше дигне. Па, врати у краву, па ужни канице, па вежи под трбу, па жавежи јако, да гу држи, да ше више не ижручи и не дај да легне крава, мора да стоји! Да дође куче да је лаје краву, крава ће устане, неће да устане, крава ће да умре. Он је гледа: - Донесте врућу воду и тај мас! Он доктор, еј, доктор ветерине не зна шта да ради. Он ће је сече, ће је оперише, ће гура оно силом. Он то уради све то како баба рекла. Више никад није дошо. Кад дође баба негде да прича како се крава тели, он кад чује баба Негу, он се врати. Баба је била велики стручњак.

[11] М. С.: Али, кад је Ђурђевдан, она треба да копа травке у Тучкову ливаду, тако се зове наша ливада доле. Или у Ђурицку бару, то тамо. Е, тамо има мечја шапа, кукурек, јао, заборавио сам шта беше још. И, сад има још неке траве. Али, има једна трава која не расте изнад земље, него та трава као тартуф - печурка, има плод у земљи, на, на два риљача негде, на једно четрдесет сантиметара, четреес пет. Е, по њеном веровању, можда је то истина, ја не знам, ако се прича, трава не може да се ископа. Она бежи, каже, све дубље и дубље, има да копаш два метра. И она мени: - Мико, ћу ти дам пет банке да пођеш да ми ишкопаш траву. Ја дечко, ови неће да је слушају. Сви: - Бежи, бабо! Свима досадила: - Само долази народ, пуна кућа народ. Не може... А даје паре она, али не тражи ником ништа. Ко јој шта да, колико даш. Ако имаш - имаш, ако немаш - ником ништа. После ћу ти причам један догађај за нека кола, кад се неке остану у другом стању, које су то враџбине! Није ни битно то! Е, да ти причам за траве. И сад, ја узмем мотику за пет банке, баш ме брига, има да купим бомбоне, иде Софроније, бомбонџија, носи бомбоне у крошњу. Макадам пут, иде деда, Македонац. Има... ено га у Шиљеговац има му посластичарску радњу син његов. Сад ја да купим за пет банке бомбоне да једем два месеца! Што да јој не копам? И ја пођем њој да копам ту траву, ал она мени каже овако: - Ту ше не прича. Ја ћу да ти пипнем шаш тојагу уш коју траву она раште. Она нема горе лишће. Та трава у жемљу. Мора копаш два риљача. Ако проговориш, она шве дубље иде. Ја ћу шам да ти пипнем ш тојагу де, а ти ће копаш. Ја кажем: - Добро. И сад, ми одемо у ливаду и ми идемо, идемо, идемо, идемо и сад, има две, између неке две траве, ја не знам, заборавио сам како се зову. Кад нађе те две траве, е та трава је некакав атрибут, нешто што прати те траве, расте са њима заједно, али је њен плод у земљи на једно четрдесетак сантиметара. Е, са том травом она прави неке лекове, не знам шта све не лечи. И лудило и све живо! И сад, она мени пипне штапом де да копам. Значи, приче нема! Ако причам, плод иде све дубље и дубље у земљу, 
не мож да га нађеш. Ја копам, копам, копам и ископам нешто као кромпир, као главица црног лука. Нешто оволико, никакав плод нема горе. Нешто као, у винограду смо ми налазили, зове се то неке орашке, то се једе. Ал то је као ора. Има једну жилку, то знам шта је, то исто нема никакав плод, али, ово је нека биљка, као кромпир, као лук, ко главица лука, више личи на кромпир. То на једно триес пет - четреес, четреес пет сантиметара је у земљи. И ми то ископамо и она га узме, баба. И, идемо, идмео, идемо, она ми покаже на друго место где има две биљке, он између тих биљака, јер она увек прати те биљке. Ја копам и нађем тај плод као кромпир. И она је од тога справљала неке лекове. То је било важно. Али, то је само копала, да л' је то било, било други дан Ђурђевдан или на дан испред Ђурђевог дана, ја то не могу да се сетим. И ево, сад ми дође прекопам целу Тучкову ливаду да би нашо, јер сад не знам које су биле, знам за мечју шапу, знам, знам која трава, не знам како се зове, могу да, да откинем, па да ти је покажем. Али сам заборавио име како се то звало. То има педесет година, човече, одакле могу да знам. И то сам ја њој копао, и она: - А, ево га Миле слуша, Микула слуша баба Негу.

[12] М. Р.: Плус ово, ја реко: - Него, немо, лебац ти... Једна кад се... да л' из Љуптен, одакле дошла... па гу давала... има живака. Као намењено, живак је... то је. Па, то ти је те врачарице што пратиле. А она да је запоји, а то је отровно. Жива, јебем ти.

А. С.: Жива? Аха.

M. Р.: Она... знам кад је... живота ми, топломер изломе да би ухватили живу.

А. С.: Аха. И шта ради с ту живу после?

М. Р.: И она ју после баје нешто. И запоји је с оно, кад изломе топломер са живу. Метла и шта беше још? Не могу се сетим то. Шта се држи докле то баје и запоји је што је учињено, знаш.

А. С.: Да је ослободи од тог живака?

М. Р.: Аха. Па, значи од тог живака. Да је на... нагазила на ил учињено...

А. С.: Аха. И она попије живу?

M. Р.: Па, дабоме, попије. Еј, боже...

[13] А. С.: А шта си ми причао за русу? Кад баје. Ајде испричај ми то опет.

М. С.: Знам само уводно. Ја сам био дете, па ме није занимало. Па, то руса, то је нека лиша, знаш. И она то нешто поред плота, нешто тамо с балегом, не знам како. Али ја знам, сећам се ми приђемо, деца, играмо се, па да чујемо:

Трута русу проси, 
Руса труту неће,

Венуће, трпеће, за труту неће.

Па, онда има читава једна песма, знаш. Бајалица. Али сад ја не знам даље, заборавио сам. Мене то није интересовало. И она то тако бајала. цем.

[14] М. Р.: Па, онда за ово, појави се, то се звало руса, као неки ек-

А. С.: Аха, болест.

M. Р.: На руке, знам да и то бајала. Изведе, па на плот, биле онда, па знаш, оне прошке. И она баје, баје, ово, па залепи ову говеђу балегу на прошку, па тако опет иде поред ово и баје да би скинула ово, све оне плое по руке.

А. С.: А је л' се сећаш шта причала то кад баје?

M. P.: А не знам то.

[15] М. Р.: Гледао сам, ето ти, запева петао - дете писне [у позадини пева петао].

A. С.: Мхм, уплаши се?

М. Р.: Знаш, плаче. И доноси, она му баје то, и узне брашно и баца и тачно се нацрта, маму му јебем. На, на, од оно кад баци од оно брашно кад баје, да л од петла или од куче. Тачно се нацрта...

А. С.: И?

М. Р.: И ено ти, они жарчићи што је бацала, за то чиње, за ово, и од кога белег од кошуљу и ово. И не знам коко жар из шпорет. И она вода, сипе. И она то баје и баца. И ово, тачно за кога мисли да је ово... Ако се не увати за онај белег. Што си донео, онај белег. Конац неки, па се направи као куглица и стави се у... Кад набаје, ако је, за кога сумњаш, значи тачно се увати онај жар.

А. С.: Увати се за жар?

M. Р.: За жар дабоме - чврррр. Кад га баци у воду и дође и увати се.

[16] М. С.: Знам и њене басне, добро. Како она оно, те њене бајалице. Она је гледала у брашно и у олово. Истопи олово, али она није могла да нађе олово овако, него имали смо оне ратне куршуме, знаш, испаљен метак нађеш, па у оној кошуљици има олово. И она то стави, нису биле пре овакве, биле једне алуминијумске кашике и онда се топило. Биле неке металне, старе, ја се сећам као дете, то смо ми звали ложице. Е, она ту ложицу гурне у шпорет или у кубе и олово се истопи и она баје бајалицу тамо: Пошла девојка, пукла јој сиса... Безобразне те бајалице. Пошла ово, пошла оно. Трута Русу проси, Рута Трусу неће, увенуће.., трте-мрте за Труту неће! Нешто у том смислу, није то ни битно, како је она то бајала. Али, кад она оно олово сипе у воду у неку чинију, то 
олово се растопи и то олово личи на неку фигуру. И она тумачи фигуру: - Е, ево ти га непријатељ. Виш ово? Ово ти, еве ти чрква. А, виш то личи на Свети Илију од олово. Има д и'ш у Свети Илију да поклониш нешто. Нема ти помоћ. Еве ти га непријатељ, то ти учинио. И, гледала у брашно. Била једна врата, огњиште позади у стару кућу. Е, та врата су била гарава од дима. Онда, ко је болестан или има неки проблем, он оде и она гледа у брашно. Она избаје, избаје, избаје и узме шаку брашно и баци на врата. Као ја кад гледам у кафу. На вратима се, врата су црна од дима, брашно је бело и онда се направи једна фигура. И она тумачи ту фигуру. И прича ти ко ти шта учинио, де ти је шта, де ти шта закопано, де да идеш.

[17] А. С.: А како баба Нега то олово... у воду то?

М. С.: Како гледа у олово?

А. С.: Ти си то видео како она ради?

M. С.: Узме куршум. Пре нису биле алуминијумске кашике, било огњиште, знаш огњиште. И сад, наравно, гори ватра, жар. Она узме, биле неке металне кашике, знаш. Гвоздене, никакве, па калаисане, неке нису калаисане. Е, она није имала олово овако. Него било пуно зрна, знаш, пушчана. Ту у Рибаре био бугарски магацин, они га запалили, изгорео. Било куршума колко оћеш. Ја сам то стављао на стрелу. Истопим олово, кад се истопи она бакарна кошуљица, остане, олово се исцеди. Она стави онај куршум, знаш, у неку кашику или можда у неку конзерву и са машице на, над ватром и олово исцури, оно се топи лако. Е, онда олово проспе у воду кад баје. Од тог олова, кад оно врело олово се сипе у хладну воду направи некаква фигурица, оно знаш? Ражљеби се нешто, личи на неку караконџулу, неку муку, нешто... личи на мајмуна. Е, онда као у шољу гледа: - E, еве, види! Учинили ти, тачно. Ааа, да ти бајем од стра. Учинили ти. Е, еве како ше направило од олово! Поглеј. Направи се нека фигурица и она тумачи облик те фигурице. А она то радила и са брашном. Бацала на врата, знаш. Била чађава врата исто ту де било огњиште, од дима. И онда она узме шаку брашна, баје, баје, баје нешто и баци на врата. Брашно се залепи и као у шољу кафе. То обично деци бајала од страха, знаш: - Од очи, одочи, урочили га. Ево! Еве! Наишо човек ша шубару, дете се пречепило од стра! Еве! Е, е да ти ја пребајем!

[18] М. С.: Онда у каленицу жарче, тамо, босиљак оно, белег. Баје нешто: - Е, нека пије мало ову воду, омите га мало ће прође!

А. С.: А како то кад баца угљевље и белег?

М. С.: Па, узме, узме босиљак ко поп, узме један чорбал... ааа земљани суд. То се зове кале... каленица. Ја мора причам у нашем жаргону. Нећу да ти причам београдски. Него причаћу рибарски, знаш. 
Каленицу она има, знаш, ону земљану. И узме босиљак и сипе воду и ти донесеш белег. Ако оћеш за неког другог, донесеш белег од неког другог. Од џемпера, знаш. Знаш шта је белег?

А. С.: Знам, знам.

М. С.: Од... обично од вунен џемпер се откине оно, од конца, па се уваља овако ко нека лоптица и она то баци у воду и узме, па прекрсти овако, ону каленицу и онда узима жар у руку, ломи га. Узме из огњишта, баци га на земљу и машицама чука, разбије онај жар и узме га у руку овако. Знаш, пребаца га из руке у руку, нешто баје: - Ајде да видим шад од чега ти је. Па, га баци: - Eeе, нее, није се уватило за белег! И баци она десетак тих угљена, знаш. И обично баца за, намени цркву де да идеш: - Да ти бацим да видим... аааа болешно ти дете. Еве... Зна, знаш: - Е, са ћу ти кажем у коју цркву. Није ти за Света Петку, немо дијеш тамо.

А. С.: А то ако се белег не увати за Света Петку онда није?

M. C.: Aха. - E, да ти набајем за Света Богородицу. Није ни тамо. За Свето... увати се за Светога Илију. Да водиш дете у Свети Илију. Еее еве увати се за белег! И онај га води. И она ту воду после, тај кога она лечила пивне, попије, знаш. Умије се и иде у цркву де она каже и после му буде боље. То, обично је бивало.

[19] М. Р.: Бога ми, бре. Па, знало то бре. Ел ти кажем. Она молила: - Ej, деца, ће ви треба то. Поготово за стоку. Пишите ово шта треба. И знам да беше покојна Цана долазила - свеску и Цана... Ова гу прича.

A.C: Она пише? Па, и Цвети исто. Цвета ми исто рекла. Исто је терала и њу.

М. Р.: Па, да. Терала, молила и...

A.С: Она запамтила...

М. Р.: И Милицу покојну.

[20] М. Р.: Она терала да учимо то. Ја нисам тео.

А. С.: А нисте тели?

M. Р.: Ууу, ја сам пцувао. Нисам то веровао. Довде ми тај народ, дан - ноћ, кад ти не можеш... зовеу... да спаваш. Од народ не можеш, то нон-стоп.

[21] А. С.: А овако у кућу колко... Јесте је поштовали ви овако, као најстаријег члана?

М. Р.: Па, како да не... Ја сам је бре, ја сам и нокти секо и чешљао. Па, ја сам на сви, и покојнем Станку... ја сам такав...

Д.: Пре се поштовало. Није то ки саде. Пре...

М. Р.: Аха. На ноге, знаш који то нокти. Старо. Ја је потопим и по сат времена и више у лавор, у воду, да омекне оно.

Д.: Је ли? Па пре се поштовало, а није ки саде. 
М. Р.: И оно није оно. И на руке. Да је то улицкам. Ја сам такав био, знаш? И овај... Имао сам то поштовање. Некад сам, кад ме изнервира нешто она, и као што сам волео да идем, и ово, ја тад тео сам да пцујем на њума. Иначе овако...

А. С.: А које године умрла? Је л' се сећаш?

М. Р.: Осемдес друге.

[22] А. С.: И шта си, шта си започео да причаш за те њене сукње кад умрла? Тео си да даш?

М. Р.: Овај, нудио сам јој ћерку. Ма, знаш које кошуље имала, то требало бре за децу. После, изађе фолклор кад игра, и Јелена и Јована. То је штета, вежено. Овде.

М.: Имала свашта.

A. C.: E?

М. Р.: Овде... живота ми. То је све било спаковано. Давао сам, и сукње, ове тканице.

А. С.: А де је то сад?

М. Р.: Тканице. Све сам попалио. Нико неће да узне. А жао ми... И све сам био изнео, имале тарабе, знаш. У двориште. Испред ону стару кућу. Па, смо правили све, стругане оне тарабе - ограда. Испред. И ја бе... оно све почело да...

Добрила: Мољци?

М. Р.: Није мољци, него почело да се као буђа декле није она то...

Д.: Мирис... онај мирис...

М. Р.: То је сваки... кад се беше оно, на кој светак?

Д.: На Видовдан.

М. Р.: Е, на Видовдан се то... она то увек износила да се препакује, преветри и опет то све сложи. Е, после, шта сам ја то реко попалио, ове шарене, штиковане (то се звало штиковане), вежене...

Д.: Па, онај бисер бео, навучено. Рупица, па...

М. Р.: Ми смо звали штиковане, а оно се... сад га зову вежене, чарапе што за у фолклор оно, шарено. То, то, то ти је паре вредело.

А. С.: Па, јесте.

М. Р.: Они... Коко она сукње имала, коко ове, кошуље, што јој жене давале, леле! То је лепота, и поче ми се ствара Нега, ја то поређам... ћe...

[23] М.: Ал, каже, кад тај дан ће да умре, она певала. Кад тај дан

M. Р.: Аха. Ја јој кажем: - Него, ће певамо? - Оћемо!

М.: Па, волела да пева.

М. Р.: Шта... „Ој Милено, Јагодо, ој Милено, јагодице“ и... за онај бор... Како се беше та песма, заборавио сам.

А. С.: Да није „Расти, расти, мој зелени боре“? 
М. Р.: Е, нека... дабоме... још које песме? Волела она: - Ће певамо? Оћемо. Значи њума је тако било само месец дана. Па, баш бре, дабоме, терао сам ја Пиљу, беше она болесна и... а, бе ја и радио. Дабоме, био сам радио у Емону. И реко ајде онај басамак био зидан, па размрдале се оне плоче. И питао сам Пиљу, реко, да га урадимо сас бетон, знаш. Плоче само да дошолујемо и да не мрда оне плоче, него да избетонира. И то увече смо бетонирали, овај, кад је то умрела.

М.: Јадна, и певала тај дан.

M. Р.: А? Певала бре. Бога ми: - Него, дођем па: - Него, како је? Добро. Овај... - Је л' ће да певамо нешто? - Оћемо.

\section{Извори илустрација}

Сл. 1, 3 и 6 - Власништво породице Ристић, љубазношћу Јелене Ристић.

Сл. 2, 4, 5 - Архив аутора.

\section{From Memories to Legend: Fieldwork as a Basis for the Reconstructing of a Portrait of a Charmer and Social Context of Charming}

\section{Ana Savić}

\section{Summary}

The article discusses a series of narratives recorded in the village of Ribare near Kruševac (central Serbia) in the period 2012-2018, told by Cveta Milić (b. 1952), Miroljub Savić (b. 1952) and Miodrag Ristić (b. 1942). The interlocutors remembered a well-known local healer and charmer, Negosava Ristić. They recalled various events from her life and comented on her personality, her healing methods and medical skills, and knowledge of conjuring. Narrated memories, combined together, compose a story of the charmer, her personal traits, beliefs and religiosity, ethics, healing and conjuring practice, her social position and influence. The paper also shows the social context of charming and natural healing, as well as the position of the charmer in the patriarchal-rural community.

Keywords: charmer, charming, healing, folk medicine, life stories, fieldwork, Ribare (Kruševac), Serbia

МА Ана Савић

Институт за књижевност и уметност Београд Е-пошта: anagarsija93@hotmail.com 